\title{
Effective uses of social media in public health and medicine: a systematic review of systematic reviews
}

\author{
Dean Giustini ${ }^{1}$, Syed Mustafa Ali $^{2}$, Matthew Fraser ${ }^{3}$, Maged N. Kamel Boulos ${ }^{3}$ \\ 1. University of British Columbia, Biomedical Branch Library, Vancouver Canada \\ 2. Mercy Corps, Islamabad, Pakistan
}

3. Alexander Graham Bell Centre for Digital Health, University of the Highlands and Islands, Elgin, United Kingdom

\begin{abstract}
Introduction: Research examining the effective uses of social media (SM) in public health and medicine, especially in the form of systematic reviews (SRs), has grown considerably in the past decade. To our knowledge, no comprehensive synthesis of this literature has been conducted to date.

Aims and methods: To conduct a systematic review of systematic reviews of the benefits and harms ("effects") of SM tools and platforms (such as Twitter and Facebook) in public health and medicine. To perform a synthesis of this literature and create a 'living systematic review'.

Results: Forty-two (42) high-quality SRs were examined. Overall, evidence of SM's effectiveness in public health and medicine was judged to be minimal. However, qualitative benefits for patients are seen in improved psychosocial support and psychological functioning. Health professionals benefited from better peer-to-peer communication and lifelong learning. Harms on all groups include the impact of SM on mental health, privacy, confidentiality and information reliability.

Conclusions: A range of negatives and positives of SM in public health and medicine are seen in the SR literature but definitive conclusions cannot be made at this time. Clearly better research designs are needed to measure the effectiveness of social technologies. For ongoing updates, see the wiki "Effective uses of social media in health: a living systematic review of systematic reviews". http://hlwiki.slais.ubc.ca/index.php/Effective uses of social media in healthcare: a living system atic review of reviews

DOI: 10.5210/ojphi.v10i2.8270

Copyright (C2018 the author(s)

This is an Open Access article. Authors own copyright of their articles appearing in the Online Journal of Public Health Informatics. Readers may copy articles without permission of the copyright owner(s), as long as the author and OJPHI are acknowledged in the copy and the copy is used for educational, not-for-profit purposes.
\end{abstract}

\section{Introduction}

The emergence of social media (SM) and social networking services to communicate in real-time and on-the-go by patients and health professionals was recognized as an important public health development more than a decade ago [1-3]. 
In 2007, Kamel Boulos described social networking services (SNSs) as collaborative, mediated environments [4], where personal computers and mobile devices can be used to foster stronger connections, and new forms of information can be shared. Some examples of SM types are wikis (e.g., Wikipedia), social networking sites (e.g., Facebook, LinkedIn), media-sharing sites (e.g., YouTube, SlideShare), blogs and micro-blogs (e.g., Blogger, Twitter), immersive worlds (e.g., Second Life), and 3-D virtual globes (e.g., Google Earth) [4].

According to the Pew Research Centre, the popularity of SNSs is linked to the adoption of healthier lifestyles and coping skills for day-to-day health concerns [5]. Pew reports that patients enjoy helping each other and sharing their healthcare experiences [5]. Patients say that the Internet is a helpful way to find answers to health problems; in fact, the research shows that frequent use of social networks is associated with increased patient awareness and empowerment [6]. Health professionals have increased their social networking via Twitter, Facebook, blogs, vlogs (video blogs, e.g., on YouTube), infotainment, games and infographics [7].

\section{Background}

In a 2013 systematic review, Moorhead et al. identified seven key ways that SM are being used in healthcare:

i. To provide information on a range of issues;

ii. To provide answers to medical questions;

iii. To facilitate dialogue between patients and health professionals;

iv. To collect data on patient experiences and opinions;

v. To use SM as a health intervention, for health promotion and health education;

vi. To reduce illness stigma; and

vii. To provide a mechanism for online consultations [8].

Social media research has improved considerably in the past decade. In fact, better empirical research is now conducted, and many higher quality studies are being published [8-10]. The aim in this SR is to conduct a qualitative synthesis of systematic reviews of the effective uses of SM in public health and medicine, both for patients and health professional groups.

\section{Methods}

This paper is a systematic review and qualitative synthesis of papers published between 2003 to 2017. The authors perform a systematic review of SRs as the volume of primary papers would have made meaningful synthesis of that literature impossible. We selected the SR methodology as it provided a more complete view of the literature and varying interventions, populations and settings. In addition, different types of papers can be compared and contrasted [11].

In exploring the relationships between studies, this SR aims to answer two questions.

1. What are the most effective uses, benefits and harms of SM usage in health and medicine? 
2. What tools are more effective (e.g., for information-sharing, communication, education, mobile and e-learning) as interventions in health programmes and services? In what ways are they beneficial or effective (or harmful), and for whom?

At the start, we registered our protocol at PROSPERO, the Prospective Register of Systematic Reviews [12]. Here, we follow the ENTREQ guidelines to enhance the transparency of our methods and to improve the reporting of the qualitative evidence [13].

\section{Information sources: bibliographic databases and search engines}

Comprehensive searches were performed in fifteen bibliographic databases and search engines from 1995 to 2017 (Table I).

\section{Table I. Bibliographic databases searched}

1. PubMed.gov

2. MEDLINE (Ovid)

3. CINAHL (EBSCO)

4. Embase (Ovid)

5. PsycINFO (EBSCO)

6. LISA: Library and Information Science Abstracts

7. Library, Information Science \& Technology Abstracts (LISTA)

8. Education Resource Information Center (ERIC) (EBSCO)

9. Academic Search Complete (EBSCO)

10. Alt Health Watch

11. Health Source

12. Communication and Mass Media Complete (3 citations)

13. Proquest Dissertations

14. Google Scholar

15. Web of Science

Reference harvesting and citation searches were conducted in Google Scholar and in the Web of Science. To locate recent papers, the authors also created current awareness alerts in databases such as MEDLINE, Embase, the Web of Science and Google Scholar. Key journals and prominent e-health journals were identified using the Web of Science and searched iteratively to increase sensitivity and to overcome any indexing deficiencies (Table II). As the top impact factor journals in e-health were available online, manual searching was conducted by scanning online tables of contents and by using the journals’ search engines. 


\section{Table II. Top E-Health and Informatics Journals (manually searched table of contents)}

Applied Clinical Informatics

BMC Medical Informatics and Decision Making

- BMC Medical Research Methodology

- CIN: Computers Informatics Nursing

- Digital Health

- Health Informatics Journal

- Informatics for Health \& Social Care

- International Journal of Medical Informatics

- Journal of the American Medical Informatics Association (JAMIA)

- Journal of Biomedical Informatics

- Journal of Medical Internet Research

- Journal of Telemedicine and Telecare

- Methods of Information in Medicine

- PLoS One

- Telemedicine and e-Health

\section{Search terms - effective uses of social media in healthcare}

The search strategies for MEDLINE and Embase were developed based on the strategies reported by Moorhead [8] and Hamm [9], and adapted accordingly. To achieve optimal sensitivity, we created strategies that combined keywords with controlled or index terms (Table III).

Table III. Keywords and their associated controlled terms for searching

A. "social media" or "social web" or "social software" or "social network*" or "web2" or "web 2.0" or "health 2.0" or "medicine 2.0" or "nursing 2.0" or "pharmacy 2.0" or "telemedicine 2.0";

B. blog* or Facebook or Flickr or Googl* or "instant messaging" or Instagram or Microblog* or Myspace or "online forum*” or PatientsLikeMe or Pinterest or podcast* or Second Life or SnapChat or Twitter or tweet* or Tumblr or "user generated content" or "video sharing" or "virtual world*" or webcast* or "web log" or WhatsApp or Wiki* or YouTube or Zotero;

C. Patient* or health consumer*;

D. "Health provider*" or "health professional*" or "physician*" or "doctor*" or "hospital*" or med* student* or pharm* student* or nurs* student*.

The following terms were added at various points in combination to refine and filter results: 
- Best practice*, benefit*, barrier*, risk*, compar*, concern*, cost*, cost-effect*, effectiv*, effectiveness, evaluat*;

- Harm*, impact, improve*, limitation*, negativ*, positiv*, private, privacy, problem*, safety, trend*, trolling, use*;

- Ehealth, e-health, e*learn*, healthcare, "health care”, medicine, public health, telehealth, mhealth

- Systematic review* or meta-analy* or systematic.

The full search strategy for Ovid MEDLINE is listed in Appendix A.

\section{Data extraction and analysis}

Our searches yielded 8521 papers from 15 bibliographic databases, search engines and manual searches (reference harvesting and citation searching). Our results were imported into RefWorks for title and abstract screening and results were loaded into MS Excel. The CASP (Critical Appraisal Skills Programme) tool for systematic reviews was used to assess the quality of papers [14]. We performed a thematic analysis using methods as described by Braun and Clarke [15].

Titles and abstracts of retrieved citations were independently coded and assessed by two reviewers (DG, SMA). Papers viewed as eligible were obtained in full-text and assessed further using predefined inclusion and exclusion criteria. Any disagreement between reviewers was resolved by a third (MNKB). Reasons for exclusion were recorded using Preferred Reporting Items for Systematic Reviews and Meta-Analyses (PRISMA). Our aim was to describe and synthesize papers but we did not attempt to determine effect sizes in the studies.

In Excel, we created columns and rows to describe the papers and their features, and piloted our spreadsheet for data extraction. Variables included the type of systematic searches performed, timeframe of searches, number of studies included, types of studies, SM tools and SNS platforms examined, study and population characteristics, focus on the interventions, outcomes measured and results, author conclusions, and broader themes and categories.

\section{Table IV. Inclusion and exclusion criteria developed using PICO}

We developed our inclusion and exclusion criteria by using our PICO and research questions:

\section{Participants/ population}

- Adults. Seniors. Young adults, late adolescents and teens. Health professionals, students and/or patients.

- Where mixed patient or health professional populations are examined, it will be important to determine the population and intervention being evaluated.

\section{Intervention(s), exposure(s)}

- Systematic reviews discussing SM as an intervention will be considered relevant.

- Web or Internet-based interventions featuring SM and information-sharing technologies are considered relevant. 
- SM applications and social networking sites (SNSs) or platforms which create a virtual network of users in a publicly-accessible environment will be considered relevant.

- The social media application must be used as part of a programme in health or medical education, public health, health promotion, health communication and/or informationsharing.

- Some online tools, such as blogs, wikis, podcasts and webcasts, and applications, such as WhatsApp and WeChat, will not necessarily be included if they do not offer the same level of dynamic interaction and real-time engagement afforded by SNSs.

\section{Comparator(s)/ control}

- Some studies will have no comparison or comparator intervention.

- Others will examine one tool against another; Facebook versus Twitter, for example.

\section{Outcome(s)}

\section{Primary \& secondary outcomes}

- Effective uses of social media, tools and applications in public health and medicine.

- Barriers, limitations and facilitators to implementing and using social media.

\section{Setting or context(s)}

- The healthcare setting will not always be specified though many of the papers with health topics will imply healthcare settings.

- The contexts may be online, "virtual" and electronic, or other social media spaces on the Web.

\section{Study type or methodology}

- The study type or methodology will be systematic in nature, with systematic searches of the literature, including a qualitative or quantitative analysis.

- Studies that are not full systematic reviews will be considered if they are deemed to have utilized systematic searches.

\section{Table V. Inclusion and exclusion criteria}

\section{Inclusion criteria}

The following criteria helped us to make final judgements with respect to inclusion:

I. Papers were published as systematic reviews in peer-reviewed journals, or as unpublished dissertations and theses, and other grey reports;

II. Papers published in English;

III. Full text was available;

IV. Study populations were more than 18 years of age and either adults, health professionals, patients, non-professional caregivers or a combination;

V. Papers analysing more than one intervention with at least one among them being social media will be included; the effects of social media should be clearly outlined; 
VI. Papers that examine online social networking sites and learning management systems, tools or platforms with a high degree of social interaction or sociality will be considered;

VII. Papers that examine effective uses of social media, including benefits and limitations will be included;

VIII. Papers scored high (>9) using the CASP Checklist for Systematic Reviews instrument.

\section{Exclusion criteria}

The following criteria helped us to make a final assessment with respect to exclusion:

- Papers considered not systematic or whose focus was not primarily on the use of social media as the major intervention studied were excluded;

- Papers that focussed primarily on paediatric or early teenage populations were not considered relevant for the review, and excluded;

- Other exclusions: studies on interventions that are considered not relevant to our review, such as studies of the Internet, ICTs (Information and Communication Technologies), websites, most tele-health and e-health related studies will be excluded unless there was a significant social media aspect;

- Papers written in languages other than ENGLISH;

- Full-text of papers were not available;

- Papers without relevant outcomes on effectiveness, benefits, limitations, harms;

- Papers that scored at 8 or below using the CASP instrument.

\section{Results}

In our searches, we identified a total of 8375 papers: 2051 in MEDLINE, 4075 in EMBASE, 1062 in CINAHL, 562 in PsycINFO, and a total of 625 from the remaining databases. Reference harvesting, search engine and manual searching added 146 papers for a total of 8521 papers (Table VI).

Deduplication and screening reduced the number of papers to 232 which were assessed for eligibility using full-text. This reduced yield to 102 papers which were then critically appraised using CASP. Two reviewers independently provided scores out of 10 for each paper by indicating "yes" to each of ten items on the CASP checklist. We had strong inter-rater agreement of the 102 papers (an overall agreement of 92\%). Discrepancies were adjudicated by a third reviewer. In the analysis, 42 papers scored high (9 out of 10) or a perfect 10 out of 10 score. 
Table VI. PRISMA flow diagram illustrating study selection

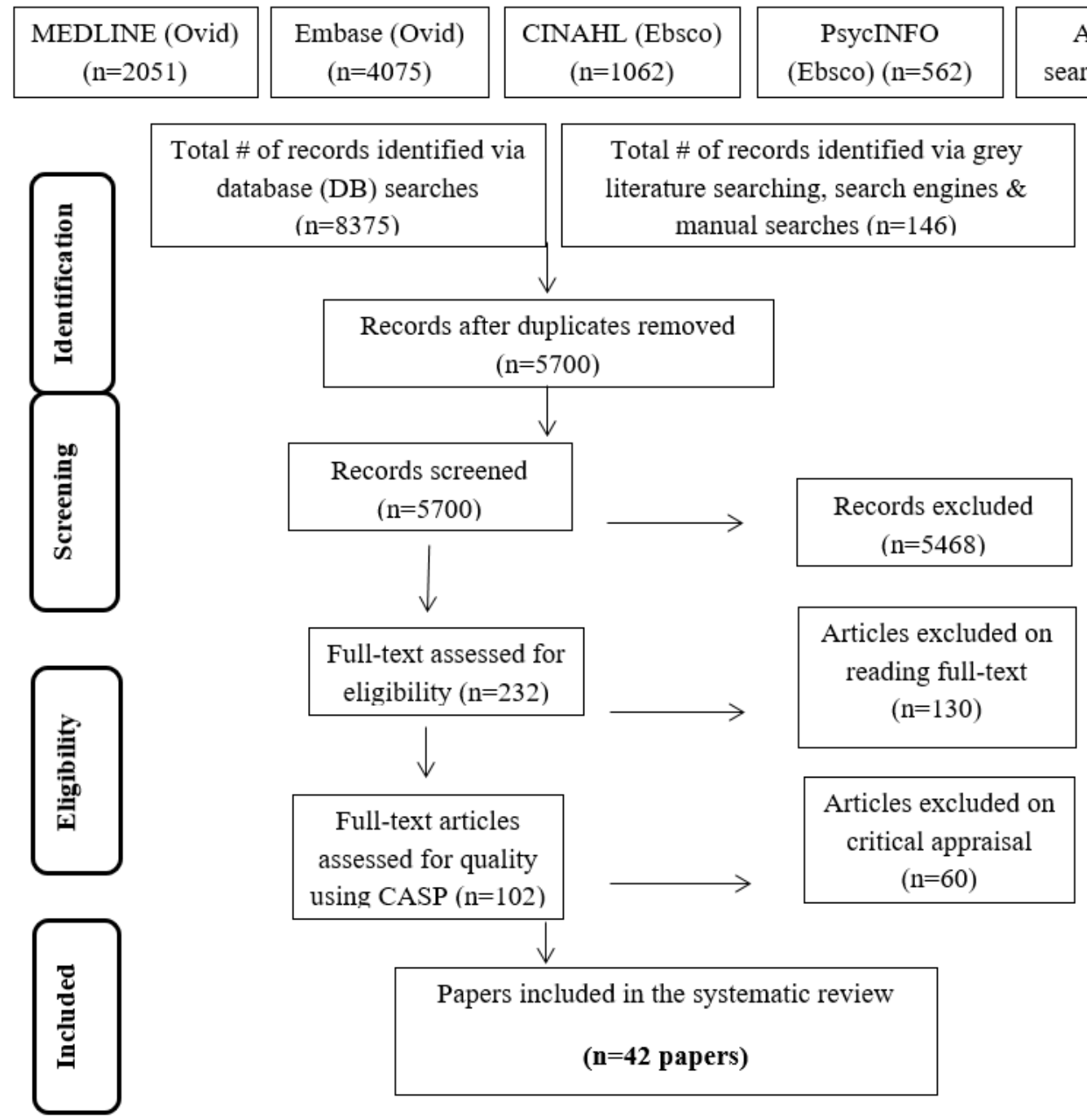

\section{Study validity}

A summary of the quality assessment of the 42 papers is contained in Appendix B.

\section{Study populations}

The study populations in the 42 papers dealt mostly with patients $(n=30)$, health professionals or health students $(n=8)$, or both patients and health professionals $(n=4)$. Ages ranged from young adults averaging 18 years of age up to adults in their senior years. The maximum age in the three studies that examined the effects of SM on older (senior) people was up to 80 years of age.

\section{Publication years of papers}

In our inclusion set, 34 papers were published between 2014 and 2016. In 2014, there were 12 papers published, with 13 papers in 2015 and 9 papers in 2016. Six papers were published between 2010 and 2013, and two papers were published in an early period from 2004 to 2009. The authors 
observed a marked increase in the number of papers published starting in 2010. (Since our searches were conducted to December 2016, we have seen a sharp increase in the numbers of papers published in 2017 and 2018 - a major reason why we have made this a living systematic review but more about that later.)

\section{Description of the included reviews}

The summary of the 42 systematic reviews in this paper are listed in Appendix C. The papers were published from 2004 to 2016. All but two (Eysenbach et al., 2004; Griffiths et al., 2009) were published between 2010 and 2016. The papers reveal a range of quantitative, qualitative and mixed method designs. A wide variance in the search strategies show a low of one reported database in one study (Househ et al., 2014) to more than 11 reported in several papers (Eysenbach et al., 2004; Williams et al., 2014; Dyson et al., 2016). The number of included papers ranged from a low of 3 (Shaw et al., 2016) to a high of 170 (Sawesi et al., 2016). The average number of included papers was 36.571 in each of the 42 included SRs.

\section{Breakdown of the \# of SRs by country of the corresponding authors ( $n=42$ papers)}

Ten papers were conducted in Australia [16-25], 9 in the United States [26-34], 8 in the United Kingdom [8,35-41], 3 in Canada [42-44] and Hong Kong [45-47], and one each in Chile [48], Italy [49], Korea [50], Mexico [51], Netherlands [52], New Zealand [53], Portugal [54], Saudi Arabia [55], and Singapore [56]. All 42 papers were written in English and available in full-text.

The included papers were published in a range of journals in public health and medicine such as informatics, general medicine and medical education. Twenty papers (47\%) were published in informatics journals; 12 of those (29\%) were published by the Journal of Medical Internet Research. Ten papers (24\%) were published in general medicine or medical education journals. The remaining papers appeared in specific biomedical journals where the focus of the systematic review seemed appropriate for the journal in question: infectious diseases $(n=3)$, pharmacy $(n=2)$, public health $(n=2)$, and one paper each in journals specializing in nutrition, paediatrics, rehabilitation and microbiology and immunology.

Table VII. Journal titles \& subject domain of included SRs

\begin{tabular}{|l|}
\hline - Journal of Medical Internet Research (12 papers) \\
\hline - JMIR Medical Informatics (1 paper) \\
\hline - Cognitive Computation (1 paper) \\
\hline - Computers in Human Behavior (1 paper) \\
\hline - Digital Health (1 paper) \\
\hline - Games for Health Journal (1 paper) \\
\hline - JAMIA (1 paper) \\
\hline - Journal of Telemedicine and Telecare (1 paper) \\
\hline
\end{tabular}


o Total: 20 papers under E-Health \& Informatics

- Medical Teacher (2 papers)

- Academic Medicine (1 paper)

- Health Education (1 paper)

o Total: 4 papers under Medical education

- PLoS One (2 papers)

- BMJ (1 paper)

- BMJ Open (1 paper)

- BMC Health Serv Res (1 paper)

- Diabetes research and clinical practice (1 paper)

o Total: 6 papers under General Medicine

- Sexually transmitted diseases (1 paper)

- Sexually Transmitted Infections (1 paper)

- Travel medicine and infectious disease (1 paper)

o Total: 3 papers under Infectious Diseases

- Human Vaccines \& Immunotherapeutics

o Total: 1 paper under Microbiology \& Immunology

- Nutrition Review (1 paper)

o Total: 1 paper under Nutrition

- Children and Youth Services Review (1 paper)

o Total: 1 paper under Paediatric Health (but covering populations >18 years old)

- Research in Social and Administrative Pharmacy (1 papers)

- British Journal of Clinical Pharmacology (1 paper)

o Total: 2 papers in Pharmacy

- BMC Public Health (1 paper)

- American Journal of Public Health (1 paper)

o Total: 2 papers in Public Health

- Disability and Rehabilitation (1 paper)

o Total: 1 paper in Rehabilitation

- HKU Theses Online (1 paper)

o Total: 1 paper in HKUTO 


\section{Thematic analysis and categorization}

The 42 papers in this review were analyzed using a method as described by Braun and Clarke [14]. The work of Thomas and Harden [57] helped to inform our thematic and narrative synthesis. Thematic analysis is a flexible means of identifying, analyzing, and reporting patterns within data [14]. Data analysis was completed by note-taking on first impressions of reading the papers. Each paper was then analyzed, and themes or categories were noted in relation to study participants, technologies or health conditions. Following the analysis of papers, a hierarchical content analysis was conducted. Themes from the reviews were coded and placed into categories. These were placed into higher order or smaller sub-themes.

According to Thomas and Harden (2008), thematic synthesis consists of three stages: coding of text 'line-by-line', development of 'descriptive themes' and a generation of 'analytical themes' [57]. While the development of descriptive themes is closely linked to the primary studies, the analytical themes represent a stage of interpretation where the reviewers 'go beyond' the primary studies and generate new interpretive constructs, explanations and hypotheses.

\section{Findings from the thematic analysis}

The thematic analysis is presented as a conceptual map in Appendix D. The conceptual map reveals the multi-dimensional nature of SM, its most common uses and tools, potential benefits and challenges. All 42 papers were classified into 9 major themes or categories:

1) Uses of social media

2) Social media formats

3) Population groups using SM

4) Technology and healthcare

5) Benefits of SM

6) Limitations (including harms) of SM

7) Disease types and prevention

8) Outcome measures

9) Psychology and emotions.

While the nine themes provide insight into the 42 papers, and aid in our categorization, we developed 97 subthemes and categories for further classificatory detail.

Our thematic analysis shows that the general public, patients and health professionals use SM for multiple reasons. In alphabetical order, the following themes emerged: behavioural changemanagement [21,24,25,31,47,49,53,54], disease prevention and management [39,47,49,53], disease surveillance [27], health education and communication [8,11,22,39,49], online learning $[24,28,32,33,37,40,41]$, online reporting and symptom reporting [25,38,41], outbreak management [27], pharmacy practice and education [16], and professional development [22].

The most common SM types were blogs [28,39,43,52], bulletin boards [20,42,53], discussion boards \& forums [20,42,53], Facebook [16,21,22,24,25,27,28,38-40,43,50,52-54], Internet chatrooms \& support groups [20], learning management systems (LMS) [46], listservs, mobile sharing apps [25], Skype [43], text-messaging applications, Twitter [21,25,28,38-40,52], 
videogames and virtual worlds [18,42,56], wikis (including Wikipedia) [16] and YouTube $[38,39,43]$.

Key populations in the thematic analysis were adolescents and teens (young people/youth $>18$ years old) [8,19,24,29,35,36,43,47,48,54], older (senior) adults (up to 80 years old) [32,45,51], health professionals [18,28,33,37,40] pharmacists [16,37], physicians [28,37,40], students in healthcare $[28,37,46]$ and vulnerable populations $[17,48,51]$.

Several important information technology themes emerged such as the use of mobile apps [25], digital technology [47], information and communication technologies [31,45], mHealth (mobile health) [25], mobile phones [25,41,45,49], social media technologies and social networking [35$38,47,48,51,54]$, tele-monitoring, video gaming [31], virtual and 3D (three-dimensional) learning environments [18,22,31,37], and Web 2.0 [22].

Recurring themes of benefits were related to increased community support [42,43], greater social connectedness [43,52], health management [8,21,25,27,31,32,41,49,53], health promotion $[24,25,39,47,49]$, Internet support groups [20,32,42], knowledge acquisition [22,40], learning opportunities [28,40] and social interaction [20,51].

Social media were used by patients across health conditions and disease types to manage depression [15,31,41], diabetes [37,52], mental health [15,31,41] and sexual health [14,19,43,50]. Other themes were increased awareness of AIDS and HIV prevention [28,37,43], medications and prescription adherence [51], immunizations and vaccinations [35,45], and obesity and weight management [16,20,21,50]. Other themes included cancer [30], cardiovascular disease [25], influenza [49], travel medicine [39], traumatic brain injury [17], infectious diseases [27], and noncommunicable diseases [53].

In papers that examined SM usage by health professionals, the following main themes emerged: medical and pharmacy education [11,23,32,34,45], e-professionalism [11,17,36], and professional development and training [11,51]. The theme of limitations (barriers and/or harms of SM) for health professionals and health students emerged in e-professionalism [16,40], media richness of tools (e.g., the degree to which they provide affordances for sharing, greater online presence and self-disclosure potential) [8,20,53], and problems related to trolling and flaming [43]. The use of SM by patients was connected to a range of negative and positive psychological themes such as depression [20,36,45], emotions [52], risk behaviours [21,27,47,54], loneliness [45,50], mental health [20,36,45], self-harm and self-inflicted injury [43], self-management [25,32], social cognitive [54], social isolation [36,45,51,53] and suicidality [43].

\section{Positive and negative effects of SM in health populations}

\section{Positive effects and benefits}

SM have been used across a range of populations with both positive and negative effects. One paper in our inclusion set is Eysenbach et al.'s highly-cited paper from 2004, which examined 45 papers from the early period of SM use from 1995 to 2003 [42]. The authors found that the benefits of peer-to-peer (P2P) communities and electronic self-support were difficult to assess with most 
studies showing 'no effects'. Some authors acknowledged anecdotal evidence of electronic selfhelp groups but recommended better evaluation to determine the precise impact $[8,36,54]$.

One large SR in our review synthesized 170 papers; a total of 112 randomized controlled trials, 7 case studies, 19 cohort studies, 15 cross-sectional analyses, and 17 quasi-experimental trials up to 2016 [31]. The authors found that 88.8\% (151/170) showed some positive impact of SM on patient behaviours and health outcomes, and $82.9 \%$ reported major improvements in patient engagement by using SM platforms [31]. For example, Facebook provided a forum for reporting personal experiences, asking questions, and receiving direct feedback for people living with diabetes [31]. Text messaging enhanced successful engagement and HIV patients used Internet-based interventions to access information and manage health problems [31]. Some patients, in using telemonitoring, video and game-based interventions, found it useful to communicate with healthcare providers via information technologies [31].

In two well-performed meta-analyses, published in 2014 and 2015 respectively, the use of SM by patients in different age groups was found to result in some self-reported and measurable changes in behaviour [21,54]. Some social networking services (SNS) showed statistically-measurable effects in promoting healthy behaviours [21,54]. In 2015, Laranjo et al. called for better research to be done in health behaviour change theory pointing out the phenomenon of social 'network alteration' where close ties and 'homophily' encourage health-behaviour-change diffusion in social networks [54]. Maher et al. reported that $90 \%$ of the papers they examined revealed significant improvements in health behaviour change. However, it was unclear whether SNS-based interventions were equally useful for all health behaviours longer term [21].

Several recent SRs published from 2014 to 2016 showed that increased interactions on SM $[34,35,41,53]$ triggered positive changes in managing health problems [8,34,35,42,52,55]. Although the effects were modest, the act of iterative information-sharing (a key activity on SM) provided benefits for patients in improved care [25,32], self-efficacy [20,21,55] and adoption of healthier lifestyles [8,26,35,55]. In public health studies from 2011 to 2015, SM were increasingly used in educating at risk and vulnerable populations $[8,19,27,48]$.

Facebook and Twitter were, from 2011 to 2016, the most preferred SM tools ( $\mathrm{n}=15$ papers), followed by blogs $(n=4)$, YouTube $(n=3)$, virtual worlds $(n=3)$, and electronic bulletin boards $(n=3)$. Facebook and Twitter were often chosen by users in meeting others and exchanging information about health concerns [8,20,35], and repeatedly used to access information and expertise $[17,24,26,35,36]$. There was little evidence statistically that they actually promoted health [35]. Adults aged 18 to 49 make up the largest group using Facebook and Twitter, and officials applied them to target demographic groups for projects in sexual health, health promotion, and in disease screening $[21,29,30]$. The affordances of Facebook and Twitter (i.e., openness or "publicness", high potential for or degree of sociality, ease of use) were well-suited to the social networking needs of most users [8].

Every one of the 42 included papers demonstrated some benefit, even the review focussed on deliberate acts of self-harm in SM [43]. Several reviews $(n=18)$ looked at effectiveness or aimed to identify the benefits or "effects" of SM in some way [9,21,24-26,33,35,36,42,45-49,52-54,58]. In three reviews, information-sharing conferred benefits, such as closer social network ties, increased emotional support, and reduced anxieties and stigma $[35,36,42]$. The sustained effects 
of SM were not proven; SM were often characterized as having potential rather than proven to be effective $[25,35,47,53]$.

Older (senior) patients were the main study populations in two papers from 2016 [45,51]. From 2013 to 2016, older adults were mentioned as the study population in several papers $[8,30,44,45,55]$. To assist older patients in coping with social isolation, SM tools were shown to be effective for some seniors. In most cases, SM should be selected with the population in mind where the best platforms have been studied empirically and deployed accordingly [45]. Research on other types of ICTs (e.g., mobile phone-based instant messaging apps) should be conducted to promote understanding of ICT-based social-isolation interventions for older people [45].

In reviews from 2011 to 2016, various diseases and health concerns were seen as the focus of interventions for depression, HIV, diabetes, cancer, heart disease, fitness, weight management and sexual health across all age ranges [19,20,26,30,33,34]. Repeatedly, papers revealed that patients and health consumers were using SM to engage in socially-supportive activity and conversations $[20,42]$. Selected e-health online social networks, such as PatientsLikeMe and Daily Strength, were mentioned in four papers $(8,48,52,54)$, but their precise benefits and effectiveness were not clearly measured.

In public health, there was growing usage of SM to educate the public about avoiding infectious agents $[19,24,49]$ and to monitor emerging health threats [27]. At least two reviews characterized SM as having benefits in public health and developing policy $[8,48]$.

Positive feedback (if not clear evidence) was provided in some studies where SM was used in online and mobile learning $[28,37,40]$. Identified benefits of using mobile-enabled SM in health education were related to the acquisition of new skills and knowledge for users on-the-go $[28,40]$. Health professionals used SM to engage in mobile and socially-distributed learning and peer-topeer interaction $[28,40,46]$. Use of Facebook and Twitter was viewed favourably and rarely associated with harmful effects in e-professionalism or social relationships [16,28,52]. Benetoli et al. showed that pharmacists accessed Facebook many times a day, using mobile devices (e.g., smartphones, tablets), but their use was restricted during work time in community pharmacies [16]. Networking with colleagues on Facebook seemed to break feelings of isolation experienced by some pharmacists, especially those in rural areas [16]. Participants reported that some dispensaries blocked Facebook [16]. The use of Facebook and Twitter in academic health was more open and focused on the lack of evidence of SM's positive or negative effects; in fact, they were shown to be equally or more effective than other platforms [37]. Commonly-cited challenges for healthcare workers using their mobiles were technical glitches (43\%), variable learner participation (43\%), and privacy/security concerns (29\%) [28].

Overall, the use of SM by health professionals was very positive with good levels of learner satisfaction [22,40]. SM resulted in increases in learner satisfaction and positive experiences for students, especially in problem-based learning [46]. One review found positive effects from the adoption of educational technologies, and listed 8 roles that tools such as digital learning objects, interactive whiteboards, plasma screens and learning management systems play in developing skills [46]. More training in using educational technologies was also mentioned [16,28,40,46]. 


\section{Problematic or negative effects of SM}

Some problematic or harmful effects of SM were seen. As social networks take larger roles in our personal and professional lives, problematic effects are increasingly likely to emerge. Some papers showed that SM has a role in increasing risky behaviours (displayed online which could be taken offline) as well as a diminished sense of well-being [8,35,45,50,52]. Balatasoukas et al. said that negative emotions expressed on SM are contagious, thereby networking the problematic behaviours [35]. The idea of contagion was why some health information shared in social networks seems to be of poor quality, a phenomenon that affects the reliability of information as it is shared 'virally'. In some cases, SM were responsible for spreading incorrect medical advice, false claims, misinformation and even fake news [8,9,30].

Much debate and polarization exist about the impact of SM on the health and mental well-being of patients [36,52], especially teenagers. Harmful effects include increased exposure to social isolation, depression and cyber-bullying [33]. Other harmful effects in younger people include the triggering of addictive behaviours, with losses in self-efficacy and confidence [50]. Further, some young adults participating in discussion forums and bulletin boards described feeling harassed and aggressively targeted (and "tracked down”) [20,42,53]. The benefits of SM for adolescents include better self-esteem and social capital, safe identity experimentation, and more opportunity for selfdisclosure with peers [33]. Facebook provided efficient ways to contact adolescents but significant positive (or negative) effects were not seen from this tracking [23]. One paper stated that adolescents progress to new media quickly, enjoy health anonymity online [33] and create hidden "secret" worlds [23]. Some users seek privacy in matters of sexual health $[19,27,48]$, HIV prevention and testing [47], and in managing their sexual behaviour [24,29].

The barriers and limitations of SM, especially on Facebook and Twitter, may be related to 'context collapse', where personal and professional boundaries can overlap undesirably [59]. When SM were used in medical education, the benefits of private social networks and learning management systems were not fully measured [46]. One problem is the failure to identify whether Facebook or Twitter are more or less effective than private platforms (or as supplements in 'blended' models). Broad use of SM is inhibited by the tension between openness on the Web and upholding medical privacy and confidentiality norms. Some adverse events were seen but they occurred infrequently confirming for some that SM can be used safely by medical educators (notwithstanding their benefits are hard to prove) $[11,17,36]$. Twelve limitations of using SM in communication was drawn to help health professionals fully appreciate all the challenges [8].

A few studies published in 2014 and 2015 raised the concern about professional misconduct for health workers and distractions related to SM use $[11,17,36]$. These concerns inhibit the use of SM generally. More robust research is needed in medical education to understand how tools and platforms can be used in mobile learning especially at a distance. The effects of SM on medical education, recruitment, and professionalism should also be studied further [28,37].

SM may lead to better social interactions for some, but recurring concerns were expressed about harms. For example, concerns about cyberbullying and its effects on the well-being of young adults were commonly expressed [36]. SM had positive effects on health provider-patient relationships, but some users express discomfort with communicating via social networks [52]. In one paper, extreme uses of SM resulted in trolling (deliberate provocation of others) and flaming (mocking 
or encouraging deliberate self-harm). In the study of detrimental effects of SM by young people, self-harm extended to increased suicidality [42]. The authors, however, pointed to a lack of evidence linking SM use and harmful behaviours, and reminded health providers to promote general Internet safety practices to avoid adverse events [42].

\section{Limitations}

\section{Evidence is inconclusive}

In this review, the evidence was revealed to be inconclusive with respect to benefits or harms. Not surprisingly, the quality of the primary research is weak. Further, the tools and platforms revealed only moderate positive and negative effects. From the evidence, little is known about the sustainability or long-term effects of these technologies. The speed at which SM tools, platforms, mobile devices and user practices change, for different populations, present difficulties for e-health researchers. Constant variation and change make it difficult to measure effects, what works and how, and this complicates any effort to compare findings in the research.

There were methodological flaws in the primary research cited in the papers we examined. For example, many papers did not pool their findings by study type or time period. Generally, there was confusion about SM terminologies, categories and definitions. Researchers using terms such as 'information and communication technologies', 'digital tools' and 'online learning platforms' are encouraged to define them and use them with more precision. Some papers did not understand the defining characteristics of SM technologies and platforms and confused them with interactive websites.

In a majority of papers $(n=20)$, conflicting results and conclusions meant that the findings were not generalizable. Findings that examined SM use in resource-rich countries, such as the United States, United Kingdom and Australia, could not be compared to poorer countries; the reverse was also true. For example, some developing countries periodically block their citizens from using Facebook and Twitter making them unreliable platforms to use in public health. Further, SM must be examined in the ecological contexts of health promotion and evidence-based decision-making; some interventions thought to be portable from one socio-economic or cultural setting or context to another were clearly not. In many SRs, SM were used as a subset of other e-health interventions making it difficult to assess specific tools and platforms.

\section{Reflections on the study methodology}

There are inherent weaknesses in the methodology we used. For our own results, we had to rely on the critical appraisal of individual studies, as well as on the interpretation of results, in each paper we examined. Further, the SRs we examined differed considerably in their study populations, interventions, comparisons and outcomes, sometimes with contradictory findings and results. Some SRs did not do a good job of specifying inclusion criteria, and literature searches were not routinely performed to high standards. As a whole, the reviews were heterogeneous; thus sensitivity, subgroup, or meta-analyses could not be performed. Due to poor quality, it was difficult to extrapolate overall themes and conclusions from dissimilar studies with any confidence. Pooling older studies ( $n=2$ from 2004 and 2009) with newer ones ( $n=40$ from 2010 to 2016) presented difficulties in longitudinal cross-comparisons as settings and contexts changed. 


\section{Future research}

Social technologies and the mobile devices used to access them (including device penetration, capabilities, user communities, digital skills of user groups) are rapidly changing. E-health researchers need more responsive approaches to evaluation that address these rapid changes. By the time an evaluation is published, the results may not apply to the current version of the tool under investigation (the latest version can often be different from the one being evaluated).

In 2015, Vandelanotte et al. said that most research examining the value of social networks has been disappointing [58]. To demonstrate the effective uses of SM in healthcare, more creative and experimental study designs will be required. Future research will have to account for the speed of change as many studies revealed that some SM tools were no longer available.

Repeatedly, we felt that the primary research was hampered by heterogeneity of interventions, and other methodological limitations. Moreover, there seems to be a need to conduct better studies, with appropriate controls, where the focus is on patients. An important emerging issue is the lack of evidence and understanding of the exponential costs of using SM. While many tools are free to use, their implementation in healthcare is not cost-neutral. Cost-effectiveness and return-oninvestment studies are needed to demonstrate value in the long term. Demonstrated economic benefits could guide future practices in the field.

To inform future research, studies should adopt better and more consistent definitions of social media. Definitions should account for more recent tools (e.g., Instagram, SnapChat, WhatsApp, WeChat, etc.), and the emergence of fraudulent research, misinformation and fake news. SNSs such as WhatsApp and Facebook have been implicated in identity theft, spreading spam, and creating trust in false information and fake treatments [60,61].

Our paper is already out of date. Many new SRs have been published recently. However, these papers will now be part of a living systematic review [62]. See our wiki http://hlwiki.slais.ubc.ca/index.php/Effective_uses_of_social_media_in_healthcare:_a_living_sy stematic_review_of_reviews where updates will be posted and papers that satisfy our inclusion criteria will be included with a brief thematic categorization.

\section{Conclusions}

SM have been widely-studied in health and medicine from 2003 to 2017 but evidence of their effectiveness is inconclusive. The positive, measurable effect of SM in the delivery of health services and programmes is lacking and the quality of papers is modest. However, our SR provides a starting point for future research and in identifying effective uses of social media. Future investigations of SM effects should focus on best practices, patient-oriented research, and the costs-benefit of using certain tools or platforms in varying healthcare settings.

Our paper suggests that SM research has entered a mobile-intensive period where patients and health professionals seek better ways to conduct their online activities and lifelong learning. Future research should identify not just how patients use SM in their daily lives but seek to understand their positive and negative effects. Researchers must examine the circumstances that lead to adoption of SM in specific ecologies and populations and undertake cost-effectiveness and return- 
on-investment studies. Better research designs in e-health are strongly needed given the increased prominence and potential value of SM in $21^{\text {st }}$ c. healthcare.

\section{References}

1. Kamel Boulos MN, Maramba I, Wheeler S. 2006. Wikis, blogs and podcasts: a new generation of Web-based tools for virtual collaborative clinical practice and education. BMC Med Educ. 6, 41. PubMed https://doi.org/10.1186/1472-6920-6-41

2. Giustini D. 2006. How Web 2.0 is changing medicine. BMJ. 333(7582), 1283-84. PubMed https://doi.org/10.1136/bmj.39062.555405.80

3. Kamel Boulos MN, Hetherington L, Wheeler S. 2007. Second Life: an overview of the potential of 3-D virtual worlds in medical and health education. Health Info Libr J. 24(4), 233-45. PubMed https://doi.org/10.1111/j.1471-1842.2007.00733.X

4. Kamel Boulos MN. Networked social media in learning, teaching and research [SlideShare]. 30 May 2010. University of Plymouth, UK. Available from: https://www.slideshare.net/sl.medic/networked-social-media-in-learning-teaching-andresearch

5. Fox S. Peer-to-peer healthcare: Many people - especially those living with chronic or rare diseases - use online connections to supplement professional medical advice. Washington, D.C: Pew Internet Research; 2011. Available from: http://www.pewinternet.org/files/oldmedia/Files/Reports/2011/Pew_P2PHealthcare_2011.pdf

6. Grosberg D, Grinvald H, Reuveni H, Magnezi R. 2016. Frequent surfing on social health networks is associated with increased knowledge and patient health activation. J Med Internet Res. 18(8), e212. PubMed https://doi.org/10.2196/jmir.5832

7. Kouri P, Rissanen ML, Weber P, Park HA. 2017. Competences in social media use in the area of health and healthcare. Stud Health Technol Inform. 232, 183-93. PubMed

8. Moorhead SA, Hazlett DE, Harrison L, Carroll JK, Irwin A, et al. 2013. A new dimension of health care: systematic review of the uses, benefits, and limitations of social media for health communication. $J$ Med Internet Res. 15(4), e85. PubMed https://doi.org/10.2196/jmir.1933

9. Hamm MP, Shulhan J, Williams G, Milne A, Scott SD, et al. 2014. A systematic review of the use and effectiveness of social media in child health. BMC Pediatr. 14, 138. PubMed https://doi.org/10.1186/1471-2431-14-138

10. McCaughey D, Baumgardner C, Gaudes A, LaRochelle D, Wu KJ, et al. 2014. Best practices in social media: Utilizing a value matrix to assess social media's impact on health care. Soc Sci Comput Rev. 32(5), 575-89. https://doi.org/10.1177/0894439314525332

11. Smith V, Devane D, Begley CM, Clarke M. 2011. Methodology in conducting a systematic review of systematic reviews of healthcare interventions. BMC Med Res Methodol. 11(1), 15. PubMed https://doi.org/10.1186/1471-2288-11-15 
12. Kamel Boulos MN, Giustini D, Wheeler S, Ali SM. Effective uses of social media in health care: a review of systematic reviews. PROSPERO protocol. 7 June 2016. Available at: http://www.crd.york.ac.uk/PROSPERO/display_record.asp?ID=CRD42016039620

13. Tong A, Flemming K, McInnes E, Oliver S, Craig J. 2012. Enhancing transparency in reporting the synthesis of qualitative research: ENTREQ. BMC Med Res Methodol. 12(1), 181. PubMed https://doi.org/10.1186/1471-2288-12-181

14. Critical Appraisal Skills Programme. CASP Systematic Review Checklist [online]. Available at: http://www.casp-uk.net/casp-tools-checklists

15. Braun V, Clarke V. 2006. Using thematic analysis in psychology. Qual Res Psychol. 3(2), 77-101. https://doi.org/10.1191/1478088706qp063oa

16. Benetoli A, Chen TF, Aslani P. 2015. The use of social media in pharmacy practice and education. Res Social Adm Pharm. 11(1), 1-46. PubMed https://doi.org/10.1016/j.sapharm.2014.04.002

17. Brunner M, Hemsley B, Palmer S, Dann S, Togher L. 2015. Review of the literature on the use of social media by people with traumatic brain injury (TBI). Disabil Rehabil. 37(17), 1511-21. PubMed https://doi.org/10.3109/09638288.2015.1045992

18. Ghanbarzadeh R, Ghapanchi AH, Blumenstein M, Talaei-Khoei A. 2014. A decade of research on the use of three-dimensional virtual worlds in health care: a systematic literature review. $J$ Med Internet Res. 16(2), e47. PubMed https://doi.org/10.2196/jmir.3097

19. Gold J, Pedrana AE, Sacks-Davis R, Hellard ME, Chang S, et al. 2011. A systematic examination of the use of online social networking sites for sexual health promotion. BMC Public Health. 11, 583. PubMed https://doi.org/10.1186/1471-2458-11-583

20. Griffiths KM, Calear AL, Banfield M. 2009. Systematic review on Internet support groups (ISGs) and depression (1): do ISGs reduce depressive symptoms? J Med Internet Res. 11(3), e40. PubMed https://doi.org/10.2196/jmir.1270

21. Maher CA, Lewis LK, Ferrar K, Marshall S, De Bourdeaudhuij I, et al. 2014. Are health behavior change interventions that use online social networks effective? A systematic review. J Med Internet Res. 16(2), e40. PubMed https://doi.org/10.2196/jmir.2952

22. Rolls K, Hansen M, Jackson D, Elliott D. 2016. How Health Care Professionals Use Social Media to Create Virtual Communities: An Integrative Review. J Med Internet Res. 18(6), e166. PubMed https://doi.org/10.2196/jmir.5312

23. Shaw JM, Mitchell CA, Welch AJ, Williamson MJ. 2015. Social media used as a health intervention in adolescent health: A systematic review of the literature. Digit Health. 1, 2055207615588395. PubMed https://doi.org/10.1177/2055207615588395

24. Swanton R, Allom V, Mullan B. 2015. A meta-analysis of the effect of new-media interventions on sexual-health behaviours. Sex Transm Infect. 91(1), 14-20. https://doi.org/10.1136/sextrans-2014-051743 
25. Whitehead L, Seaton P. 2016. The Effectiveness of Self-Management Mobile Phone and Tablet Apps in Long-term Condition Management: A Systematic Review. J Med Internet Res. 18(5), e97. PubMed https://doi.org/10.2196/jmir.4883

26. Chang T, Chopra V, Zhang C, Woolford SJ. 2013. The role of social media in online weight management: systematic review. J Med Internet Res. 15(11), e262. PubMed https://doi.org/10.2196/jmir.2852

27. Charles-Smith LE, Reynolds TL, Cameron MA, Conway M, Lau EH, et al. 2015. Using social media for actionable disease surveillance and outbreak management: A systematic literature review. PLoS One. 10(10), e0139701. PubMed https://doi.org/10.1371/journal.pone.0139701

28. Cheston CC, Flickinger TE, Chisolm MS. 2013. Social media use in medical education: a systematic review. Acad Med. 88(6), 893-901. PubMed https://doi.org/10.1097/ACM.0b013e31828ffc23

29. Jones K, Eathington P, Baldwin K, Sipsma H. 2014. The impact of health education transmitted via social media or text messaging on adolescent and young adult risky sexual behavior: A systematic review of the $\begin{array}{lllll}\text { literature. Sex } & \text { Transm } & \text { Dis. } & \text { 41(7), } & \text { 413-19. }\end{array}$ https://doi.org/10.1097/OLQ.0000000000000146

30. Koskan A, Klasko L, Davis SN, Gwede CK, Wells KJ, et al. 2014. Use and taxonomy of social media in cancer-related research: a systematic review. Am J Public Health. 104(7), e20-37. PubMed https://doi.org/10.2105/AJPH.2014.301980

31. Sawesi S, Rashrash M, Phalakornkule K, Carpenter JS, Jones JF. 2016. The impact of information technology on patient engagement and health behavior change: a systematic review of the literature. JMIR Med Inform. 4(1), e1. PubMed https://doi.org/10.2196/medinform.4514

32. Stellefson M, Chaney B, Barry AE, Chavarria E, Tennant B, et al. 2013. Web 2.0 chronic disease self-management for older adults: a systematic review. J Med Internet Res. 15(2), e35. PubMed https://doi.org/10.2196/jmir.2439

33. Taggart T, Grewe ME, Conserve DF, Gliwa C, Roman Isler M. 2015. Social media and HIV: a systematic review of uses of social media in HIV communication. J Med Internet Res. 17(11), e248. PubMed https://doi.org/10.2196/jmir.4387

34. Willis EA, Szabo-Reed AN, Ptomey LT, Steger FL, Honas JJ, Washburn RA, Donnelly JE. Do weight management interventions delivered by online social networks effectively improve body weight, body composition, and chronic disease risk factors? A systematic review. J Telemed Telecare. 2016 Feb 15. pii: 1357633X16630846

35. Balatsoukas P, Kennedy CM, Buchan I, Powell J, Ainsworth J. 2015. The role of social network technologies in online health promotion: a narrative review of theoretical and empirical factors influencing intervention effectiveness. J Med Internet Res. 17(6). PubMed https://doi.org/10.2196/jmir.3662

36. Best P, Manktelow R, Taylor B. 2014. Online communication, social media and adolescent wellbeing: a systematic narrative review. Child Youth Serv Rev. 41, 27-36. https://doi.org/10.1016/j.childyouth.2014.03.001 
37. Cartledge P, Miller M, Phillips B. 2013. The use of social networking sites in medical education. Med Teach. 35(10), 847-57. PubMed https://doi.org/10.3109/0142159X.2013.804909

38. Golder S, Norman G, Loke YK. 2015. Systematic review on the prevalence, frequency and comparative value of adverse events data in social media. Br J Clin Pharmacol. 80(4), 878-88. PubMed https://doi.org/10.1111/bcp.12746

39. Patel D, Jermacane D. 2015. Social media in travel medicine: A review. Travel Med Infect Dis. 13(2), 135-42. PubMed https://doi.org/10.1016/j.tmaid.2015.03.006

40. Smith T, Lambert R. 2014. A systematic review investigating the use of Twitter and Facebook in universitybased healthcare education. Health Educ. 114(5), 347-66. https://doi.org/10.1108/HE-07-2013$\underline{0030}$

41. Toma T, Athanasiou T, Harling L, Darzi A, Ashrafian H. Online social networking services in the management of patients with diabetes mellitus: systematic review and meta-analysis of randomised controlled

42. Eysenbach G, Powell J, Englesakis M, Rizo C, Stern A. 2004. Health related virtual communities and electronic support groups: systematic review of the effects of online peer to peer interactions. BMJ. 328(7449), 1166. PubMed https://doi.org/10.1136/bmj.328.7449.1166

43. Dyson MP, Hartling L, Shulhan J, Chisholm A, Milne A, et al. 2016. A systematic review of social media use to discuss and view deliberate self-harm acts. PLoS One. 11(5), e0155813. PubMed https://doi.org/10.1371/journal.pone.0155813

44. Williams G, Hamm MP, Shulhan J, Vandermeer B, Hartling L. 2014. Social media interventions for diet and exercise behaviours: a systematic review and meta-analysis of randomised controlled trials. BMJ Open. 4(2), e003926. PubMed https://doi.org/10.1136/bmjopen-2013-003926

45. Chen YR, Schulz PJ. 2016. The effect of information communication technology interventions on reducing social isolation in the elderly: a systematic review. J Med Internet Res. 18(1). $\underline{\text { PubMed }}$ https://doi.org/10.2196/jmir.4596

46. Jin J, Bridges SM. 2014. Educational technologies in problem-based learning in health sciences education: a systematic review. J Med Internet Res. 16(12). PubMed https://doi.org/10.2196/jmir.3240

47. Luo B. The effectiveness of social networking interventions for HIV prevention: a systematic review. HKU Theses Online (HKUTO). 2015

48. Capurro D, Cole K, Echavarría MI, Joe J, Neogi T, et al. 2014. The use of social networking sites for public health practice and research: a systematic review. J Med Internet Res. 16(3), e79. PubMed https://doi.org/10.2196/jmir.2679

49. Odone A, Ferrari A, Spagnoli F, Visciarelli S, Shefer A, et al. 2015. Effectiveness of interventions that apply new media to improve vaccine uptake and vaccine coverage. Hum Vaccin Immunother. 11(1), 72-82. PubMed https://doi.org/10.4161/hv.34313 
50. Song H, Zmyslinski-Seelig A, Kim J, Drent A, Victor A, et al. 2014. Does Facebook make you lonely?: A meta analysis. Comput Human Behav. 36, 446-52. https://doi.org/10.1016/j.chb.2014.04.011

51. Campos W, Martinez A, Sanchez W, Estrada H, Castro-Sánchez NA, et al. 2016. A systematic review of proposals for the social integration of elderly people using ambient intelligence and social networking sites. Cognit Comput. 8(3), 529-42. https://doi.org/10.1007/s12559-016-9382-z

52. Smailhodzic E, Hooijsma W, Boonstra A, Langley DJ. 2016. Social media use in healthcare: A systematic review of effects on patients and on their relationship with healthcare professionals. BMC Health Serv Res. 16, 442. PubMed https://doi.org/10.1186/s12913-016-1691-0

53. Mita G, Ni Mhurchu C, Jull A. 2016. Effectiveness of social media in reducing risk factors for noncommunicable diseases: a systematic review and meta-analysis of randomized controlled trials. Nutr Rev. 74(4), 237-47. PubMed https://doi.org/10.1093/nutrit/nuv106

54. Laranjo L, Arguel A, Neves AL, Gallagher AM, Kaplan R, et al. 2015. The influence of social networking sites on health behavior change: a systematic review and meta-analysis. J Am Med Inform Assoc. 22(1), 243-56. PubMed https://doi.org/10.1136/amiajnl-2014-002841

55. Househ M, Borycki E, Kushniruk A. 2014. Empowering patients through social media: the benefits and challenges. Health Informatics J. 20(1), 60-68. https://doi.org/10.1177/1460458213476969

56. Theng YL, Lee JW, Patinadan PV, Foo SS. 2015. The use of videogames, gamification and virtual environments in the self-management of diabetes: a systematic review of evidence. Games Health J. 4(5), 352-61. PubMed https://doi.org/10.1089/g4h.2014.0114

57. Thomas J, Harden A. 2008. Methods for the thematic synthesis of qualitative research in systematic reviews. BMC Med Res Methodol. 8(1), 45. PubMed https://doi.org/10.1186/1471-2288-8-45

58. Vandelanotte C, Maher CA. 2015. Why we need more than just randomized controlled trials to establish the effectiveness of online social networks for health behavior change. Am J Health Promot. 30(2), 7476. PubMed https://doi.org/10.4278/ajhp.141204-CIT-605

59. Vitak J. 2012. The impact of context collapse and privacy on social network site disclosures. J Broadcast Electron Media. 56, 451-70. https://doi.org/10.1080/08838151.2012.732140

60. Fernández-Luque L, Bau T. 2015. Health and social media: perfect storm of information. Healthc Inform Res. 21(2), 67-73. PubMed https://doi.org/10.4258/hir.2015.21.2.67

61. Viviani M, Pasi G. 2017. Credibility in social media: opinions, news, and health information—a survey. Wiley Interdiscip Rev Data Min Knowl Discov. https://doi.org/10.1002/widm.1209

62. Elliott JH, Turner T, Clavisi O, Thomas J, Higgins JP, et al. 2014. Living systematic reviews: an emerging opportunity to narrow the evidence-practice gap. PLoS Med. 11(2), e1001603. PubMed https://doi.org/10.1371/journal.pmed.1001603 
63. Sandelowski M, Leeman J. 2012. Writing usable qualitative health research findings. Qual Health Res. 22(10), 1404-13. PubMed https://doi.org/10.1177/1049732312450368 


\title{
Appendix A. Sample Search Strategy (MEDLINE)
}

\section{Database: MEDLINE via Ovid <1946 to Present file $>$}

Search Title: Effective uses of social media in public health and medicine

Search dates: 25 June 2016, updated 5 December 2016

Results: 2051

\author{
Internet and social media related MeSH: \\ 1. Blogging/ \\ 2. Computer-Assisted Instruction/ \\ 3. Computer Communication Networks/ \\ 4. Computers/td, ut \\ 5. Electronic Mail/ \\ 6. exp Internet/ \\ 7. Mass Media/td, ut \\ 8. Medical Informatics/ \\ 9. Online Systems/td, ut \\ 10. Search Engine/ \\ 11. Social Media/ \\ 12. User-Computer Interface/
}

Internet and social medial related keywords:

13. blog*.mp.

14. Facebook*.mp.

15. (forum* adj3 (internet or web* or chat*)).mp.

16. Googl*.mp.

17. "Health 2.0".mp.or "Medicine 2.0".mp.

18. microblog*.mp.

19. myspace.mp.

20. (online or on-line).mp.

21. PatientsLikeMe.mp.

22. podcast*.mp.

23. Second Life.mp. 
24. (social adj3 media*).mp.

25. (Social adj3 network*).mp.

26. (twitter or tweet*).mp.

27. user generated content.mp.

28. (virtual adj3 (world* or communit*)).mp.

29. ("Web 2.0" or "Web 2").mp.

30. web-based.mp.

31. WebMD.mp.

32. (website* or web site* or webpage* or web page*).mp.

33. wiki*.mp.

34. World Wide Web.mp.

35. YouTube.mp.

36. or/1-35 [Internet/social media MeSH and keywords]

Health care, patient care, self-care, information-sharing terms

37. exp Attitude to Health/

38. exp Health Education/

39. exp Health Promotion/

40. exp Health/

41. exp Self Care/

42. exp Self-Help Groups/

43. Communication/

44. "Delivery of Health Care"/

45. health behavior/

46. Health Communication/

47. Information Dissemination/

48. Information Seeking Behavior/

49. Information Services/

50. "Information Storage and Retrieval"/

51. Patient Care/

52. social support/

53. (health adj3 (behavio?r* or care or communicat* or educat* or promot* or service*)).mp. 
54. (inform* adj3 (disseminat* or retriev* or seek* or service*)).mp.

55. (self adj3 (care or help or support*)).tw.

56. or/36-54 [MeSH words for health promotion/information seeking]

57. 36 and 55 [combination of social media + health information terms]

Search filters to identify effective uses, best practices and harms

\section{Best practice*.mp.}

59. benefit*.mp.

60. concern*.mp.

61. confidential*.mp.

62. cost*.mp. or cost-effect* or effective*

63. impact*.mp. or limitation**.mp. or negativ*.mp. or positive*.mp. or problem*.mp.

64. risk*.mp. or harm*.mp. or safety.mp.

65. troll*.mp. or trend*.mp.

66. or/ 58-65

SR Filter (to filter out non-systematic review research)

67. meta analysis.mp,pt.

68. systematic review.mp,pt.

69. search*.tw.

70. or/67-69 [HIRU SR filter to balance sensitivity and specificity]

Limits: publication years 2003-2016 


\section{Appendix B. Quality assessment of the 42 papers}

\begin{tabular}{|c|c|c|c|c|c|c|c|c|c|c|c|c|}
\hline \multirow{2}{*}{$\begin{array}{l}\text { Papers included in this } \\
\text { review }\end{array}$} & \multicolumn{10}{|c|}{ Quality Assessment Indicators - CASP Tool for Systematic Reviews } & \multirow[t]{2}{*}{$\mathbf{I}$} & \multirow[t]{2}{*}{ II } \\
\hline & $\begin{array}{l}\text { Focused } \\
\text { question }\end{array}$ & $\begin{array}{l}\text { Right } \\
\text { type of } \\
\text { papers }\end{array}$ & $\begin{array}{l}\text { Relevant } \\
\text { studies } \\
\text { included }\end{array}$ & $\begin{array}{l}\text { Quality } \\
\text { assessment }\end{array}$ & $\begin{array}{l}\text { Combined } \\
\text { results }\end{array}$ & $\begin{array}{l}\text { Overall } \\
\text { results }\end{array}$ & $\begin{array}{l}\text { Precision } \\
\text { of results }\end{array}$ & $\begin{array}{l}\text { Applicable } \\
\text { to local } \\
\text { population }\end{array}$ & $\begin{array}{l}\text { Important } \\
\text { outcome } \\
\text { considered }\end{array}$ & $\begin{array}{l}\text { Benefits } \\
\text { worth harm } \\
\text { and cost }\end{array}$ & & \\
\hline Balatsoukas et al, 2015 & $\checkmark$ & $\checkmark$ & $\checkmark$ & - & $\checkmark$ & $\checkmark$ & $\checkmark$ & $\checkmark$ & $\checkmark$ & $\checkmark$ & 9 & 9 \\
\hline Benetoli et al, 2015 & $\checkmark$ & $\checkmark$ & $\checkmark$ & - & $\checkmark$ & $\checkmark$ & $\checkmark$ & $\checkmark$ & $\checkmark$ & $\checkmark$ & 9 & 9 \\
\hline Best et al, 2014 & $\checkmark$ & $\checkmark$ & $\checkmark$ & $\checkmark$ & $\checkmark$ & $\checkmark$ & $\checkmark$ & $\checkmark$ & $\checkmark$ & $\checkmark$ & 10 & 10 \\
\hline Brunner et al, 2015 & $\checkmark$ & $\checkmark$ & $\checkmark$ & - & $\checkmark$ & $\checkmark$ & $\checkmark$ & $\checkmark$ & $\checkmark$ & $\checkmark$ & 9 & 9 \\
\hline Campos et al, 2016 & $\checkmark$ & $\checkmark$ & $\checkmark$ & $\checkmark$ & $\checkmark$ & $\checkmark$ & $\checkmark$ & $\checkmark$ & $\checkmark$ & $\checkmark$ & 10 & 10 \\
\hline Capurro et al, 2014 & $\checkmark$ & $\checkmark$ & $\checkmark$ & $\checkmark$ & $\checkmark$ & $\checkmark$ & - & $\checkmark$ & $\checkmark$ & $\checkmark$ & 9 & 9 \\
\hline Cartledge et al, 2013 & $\checkmark$ & $\checkmark$ & $\checkmark$ & $\checkmark$ & $\checkmark$ & $\checkmark$ & $\checkmark$ & $\checkmark$ & $\checkmark$ & $\checkmark$ & 10 & 10 \\
\hline Chang et al, 2013 & $\checkmark$ & $\checkmark$ & $\checkmark$ & - & $\checkmark$ & $\checkmark$ & $\checkmark$ & $\checkmark$ & $\checkmark$ & $\checkmark$ & 10 & 9 \\
\hline Charles-Smith et al, 2015 & $\checkmark$ & $\checkmark$ & $\checkmark$ & $\checkmark$ & $\checkmark$ & $\checkmark$ & $\checkmark$ & $\checkmark$ & $\checkmark$ & $\checkmark$ & 10 & 10 \\
\hline Chen et al, 2016 & $\checkmark$ & $\checkmark$ & $\checkmark$ & $\checkmark$ & $\checkmark$ & $\checkmark$ & - & $\checkmark$ & $\checkmark$ & $\checkmark$ & 10 & 9 \\
\hline Cheston et al, 2013 & $\checkmark$ & $\checkmark$ & $\checkmark$ & $\checkmark$ & $\checkmark$ & $\checkmark$ & $\checkmark$ & $\checkmark$ & $\checkmark$ & $\checkmark$ & 10 & 9 \\
\hline Dyson et al, 2016 & $\checkmark$ & $\checkmark$ & $\checkmark$ & $\checkmark$ & $\checkmark$ & $\checkmark$ & $\checkmark$ & $\checkmark$ & $\checkmark$ & $\checkmark$ & 10 & 10 \\
\hline Eysenbach et al, 2004 & $\checkmark$ & $\checkmark$ & $\checkmark$ & - & $\checkmark$ & $\checkmark$ & $\checkmark$ & $\checkmark$ & $\checkmark$ & $\checkmark$ & 9 & 9 \\
\hline Ghanbarzadeh et al, 2014 & $\checkmark$ & $\checkmark$ & $\checkmark$ & - & $\checkmark$ & $\checkmark$ & $\checkmark$ & $\checkmark$ & $\checkmark$ & $\checkmark$ & 9 & 9 \\
\hline Gold et al, 2011 & $\checkmark$ & $\checkmark$ & $\checkmark$ & $\checkmark$ & $\checkmark$ & $\checkmark$ & - & $\checkmark$ & $\checkmark$ & $\checkmark$ & 9 & 9 \\
\hline Golder et al, 2015 & $\checkmark$ & $\checkmark$ & $\checkmark$ & $\checkmark$ & $\checkmark$ & $\checkmark$ & $\checkmark$ & $\checkmark$ & $\checkmark$ & $\checkmark$ & 10 & 10 \\
\hline Griffiths et al, 2009 & $\checkmark$ & $\checkmark$ & $\checkmark$ & - & $\checkmark$ & $\checkmark$ & $\checkmark$ & $\checkmark$ & $\checkmark$ & $\checkmark$ & 10 & 9 \\
\hline Househ et al, 2014 & $\checkmark$ & $\checkmark$ & $\checkmark$ & - & $\checkmark$ & $\checkmark$ & $\checkmark$ & $\checkmark$ & $\checkmark$ & $\checkmark$ & 9 & 9 \\
\hline
\end{tabular}




\begin{tabular}{|c|c|c|c|c|c|c|c|c|c|c|c|c|}
\hline Jin et al, 2014 & $\checkmark$ & $\checkmark$ & $\checkmark$ & - & $\checkmark$ & $\checkmark$ & $\checkmark$ & $\checkmark$ & $\checkmark$ & $\checkmark$ & 9 & 9 \\
\hline Jones et al, 2014 & $\checkmark$ & $\checkmark$ & $\checkmark$ & - & $\checkmark$ & $\checkmark$ & $\checkmark$ & $\checkmark$ & $\checkmark$ & $\checkmark$ & 9 & 9 \\
\hline Koskan et al, 2014 & $\checkmark$ & $\checkmark$ & $\checkmark$ & - & $\checkmark$ & $\checkmark$ & $\checkmark$ & $\checkmark$ & $\checkmark$ & $\checkmark$ & 9 & 9 \\
\hline Laranjo et al, 2015 & $\checkmark$ & $\checkmark$ & $\checkmark$ & $\checkmark$ & $\checkmark$ & $\checkmark$ & $\checkmark$ & $\checkmark$ & $\checkmark$ & $\checkmark$ & 10 & 10 \\
\hline Luo 2015 & $\checkmark$ & $\checkmark$ & $\checkmark$ & $\checkmark$ & $\checkmark$ & $\checkmark$ & $\checkmark$ & $\checkmark$ & $\checkmark$ & $\checkmark$ & 10 & 10 \\
\hline Maher et al. 2014 & $\checkmark$ & $\checkmark$ & $\checkmark$ & $\checkmark$ & $\checkmark$ & $\checkmark$ & $\checkmark$ & $\checkmark$ & $\checkmark$ & $\checkmark$ & 10 & 9 \\
\hline McAlpine et al 2015 & $\checkmark$ & $\checkmark$ & $\checkmark$ & - & $\checkmark$ & $\checkmark$ & $\checkmark$ & $\checkmark$ & $\checkmark$ & $\checkmark$ & 9 & 8 \\
\hline Merolli et al 2013 & $\checkmark$ & $\checkmark$ & $\checkmark$ & - & $\checkmark$ & $\checkmark$ & $\checkmark$ & $\checkmark$ & $\checkmark$ & $\checkmark$ & 9 & 8 \\
\hline Mita et al. 2016 & $\checkmark$ & $\checkmark$ & $\checkmark$ & $\checkmark$ & $\checkmark$ & $\checkmark$ & $\checkmark$ & $\checkmark$ & $\checkmark$ & $\checkmark$ & 10 & 9 \\
\hline Moorhead et al. 2013 & $\checkmark$ & $\checkmark$ & $\checkmark$ & $\checkmark$ & $\checkmark$ & $\checkmark$ & - & $\checkmark$ & $\checkmark$ & $\checkmark$ & 9 & 10 \\
\hline $\begin{array}{l}\text { Newbold and Campos } \\
2011\end{array}$ & $\checkmark$ & $\checkmark$ & $\checkmark$ & - & $\checkmark$ & $\checkmark$ & - & $\checkmark$ & $\checkmark$ & $\checkmark$ & 9 & 8 \\
\hline Ngwenya and Mills 2014 & $\checkmark$ & $\checkmark$ & $\checkmark$ & - & $\checkmark$ & $\checkmark$ & - & $\checkmark$ & $\checkmark$ & $\checkmark$ & 9 & 8 \\
\hline Odone et al. 2015 & $\checkmark$ & $\checkmark$ & $\checkmark$ & $\checkmark$ & $\checkmark$ & $\checkmark$ & $\checkmark$ & $\checkmark$ & $\checkmark$ & $\checkmark$ & 10 & 9 \\
\hline Pander et al. 2014 & $\checkmark$ & $\checkmark$ & $\checkmark$ & - & $\checkmark$ & $\checkmark$ & $\checkmark$ & $\checkmark$ & $\checkmark$ & $\checkmark$ & 9 & 8 \\
\hline Patel et al. 2015 & $\checkmark$ & $\checkmark$ & $\checkmark$ & $\checkmark$ & $\checkmark$ & $\checkmark$ & $\checkmark$ & $\checkmark$ & $\checkmark$ & $\checkmark$ & 10 & 9 \\
\hline Rice et al. 2014 & $\checkmark$ & $\checkmark$ & $\checkmark$ & - & $\checkmark$ & $\checkmark$ & $\checkmark$ & $\checkmark$ & $\checkmark$ & $\checkmark$ & 9 & 8 \\
\hline Robinson et al. 2015 & $\checkmark$ & $\checkmark$ & $\checkmark$ & - & $\checkmark$ & $\checkmark$ & $\checkmark$ & $\checkmark$ & $\checkmark$ & $\checkmark$ & 9 & 8 \\
\hline Rolls et al. 2016 & $\checkmark$ & $\checkmark$ & $\checkmark$ & $\checkmark$ & $\checkmark$ & $\checkmark$ & $\checkmark$ & $\checkmark$ & $\checkmark$ & $\checkmark$ & 10 & 9 \\
\hline Sarker et al. 2015 & $\checkmark$ & $\checkmark$ & $\checkmark$ & - & $\checkmark$ & $\checkmark$ & $\checkmark$ & $\checkmark$ & $\checkmark$ & $\checkmark$ & 9 & 8 \\
\hline Sawesi et al. 2016 & $\checkmark$ & $\checkmark$ & $\checkmark$ & $\checkmark$ & $\checkmark$ & $\checkmark$ & $\checkmark$ & $\checkmark$ & $\checkmark$ & $\checkmark$ & 10 & 9 \\
\hline Schnall et al. 2014 & $\checkmark$ & $\checkmark$ & $\checkmark$ & $\checkmark$ & $\checkmark$ & $\checkmark$ & $\checkmark$ & $\checkmark$ & - & $\checkmark$ & 9 & 8 \\
\hline Shaw et al. 2015 & $\checkmark$ & $\checkmark$ & - & $\checkmark$ & $\checkmark$ & $\checkmark$ & $\checkmark$ & $\checkmark$ & $\checkmark$ & $\checkmark$ & 9 & 9 \\
\hline Smailhodzic et al, 2016 & $\checkmark$ & $\checkmark$ & $\checkmark$ & $\sqrt{ }$ & $\bar{\checkmark}$ & $\checkmark$ & $\checkmark$ & $\checkmark$ & $\checkmark$ & $\checkmark$ & 10 & 10 \\
\hline
\end{tabular}


Effective uses of social media in public health and medicine: a systematic review of systematic reviews

\begin{tabular}{|c|c|c|c|c|c|c|c|c|c|c|c|c|}
\hline Smith and Lambert 2014 & $\checkmark$ & $\checkmark$ & $\checkmark$ & $\checkmark$ & $\checkmark$ & $\checkmark$ & $\checkmark$ & $\checkmark$ & $\checkmark$ & $\checkmark$ & 10 & 9 \\
\hline Song et al. 2014 & $\checkmark$ & $\checkmark$ & $\checkmark$ & - & $\checkmark$ & $\checkmark$ & $\checkmark$ & $\checkmark$ & $\checkmark$ & $\checkmark$ & 9 & 9 \\
\hline Stellesfson et al. 2013 & $\checkmark$ & $\checkmark$ & $\checkmark$ & $\checkmark$ & $\checkmark$ & $\checkmark$ & $\checkmark$ & $\checkmark$ & $\checkmark$ & $\checkmark$ & 10 & 10 \\
\hline Swanton et al. 2015 & $\checkmark$ & $\checkmark$ & $\checkmark$ & $\checkmark$ & $\checkmark$ & $\checkmark$ & $\checkmark$ & $\checkmark$ & $\checkmark$ & $\checkmark$ & 10 & 9 \\
\hline Taggart et al. 2015 & $\checkmark$ & $\checkmark$ & $\checkmark$ & $\checkmark$ & $\checkmark$ & $\checkmark$ & - & $\checkmark$ & $\checkmark$ & $\checkmark$ & 9 & 9 \\
\hline Theng et al. 2015 & $\checkmark$ & $\checkmark$ & $\checkmark$ & $\checkmark$ & $\checkmark$ & $\checkmark$ & - & $\checkmark$ & $\sqrt{ }$ & $\checkmark$ & 9 & 9 \\
\hline Toma et al. 2014 & $\checkmark$ & $\checkmark$ & $\checkmark$ & $\checkmark$ & $\checkmark$ & $\checkmark$ & $\checkmark$ & $\checkmark$ & $\checkmark$ & $\checkmark$ & 10 & 9 \\
\hline $\begin{array}{l}\text { Whitehead and Seaton } \\
2016\end{array}$ & $\checkmark$ & $\checkmark$ & $\checkmark$ & $\checkmark$ & $\checkmark$ & $\checkmark$ & - & $\checkmark$ & $\checkmark$ & $\checkmark$ & 9 & 9 \\
\hline Williams et al. 2014 & $\checkmark$ & $\checkmark$ & $\checkmark$ & $\checkmark$ & $\checkmark$ & $\checkmark$ & $\checkmark$ & $\checkmark$ & $\checkmark$ & $\checkmark$ & 10 & 9 \\
\hline Willis et al. 2016 & $\checkmark$ & $\checkmark$ & $\checkmark$ & $\checkmark$ & $\checkmark$ & $\checkmark$ & N/A & $\checkmark$ & $\checkmark$ & $\checkmark$ & 9 & 9 \\
\hline
\end{tabular}




\section{Appendix C. Summary of the 42 systematic reviews}

\begin{tabular}{|c|c|c|c|}
\hline Study & Main aims & Type of study, methods, topic, population & Included papers \& main findings \\
\hline $\begin{array}{l}\text { Balatsoukas et } \\
\text { al, } 2015 \text { [35] }\end{array}$ & $\begin{array}{l}\text { To review research on } \\
\text { integration of expert-led } \\
\text { health promotion } \\
\text { interventions with online } \\
\text { social networking sites } \\
\text { (SNSs). }\end{array}$ & $\begin{array}{l}\text { - Scoping search and systematic narrative } \\
\text { synthesis. } \\
\text { - The effectiveness of SNS for health promotion. } \\
\text { - Various (adults, families, students, general web } \\
\text { users, office workers, patients, children and } \\
\text { parents, youth, teenage girls, adolescents). }\end{array}$ & $\begin{array}{l}\text { - } 42 \text { papers included. } \\
\text { - } 26 \text { papers evaluated effectiveness; } 6 \text { RCTs, } 4 \\
\text { observational, } 14 \text { pilot studies, other (2). } \\
\text { - RCTs showed no clear effect of SNSs; more positive } \\
\text { effects on both self-reported and objectively measured } \\
\text { behaviour change were reported in pilot studies. } \\
\text { - There are positive effects on emotional health if positive } \\
\text { experiences are shared. However, this can also be } \\
\text { negative, due to contagion of negative emotions. }\end{array}$ \\
\hline $\begin{array}{l}\text { Benetoli et al, } \\
2015 \\
\text { (Australia) } \\
\text { [16] }\end{array}$ & $\begin{array}{l}\text { To investigate the use of } \\
\text { SM in professional } \\
\text { pharmacy practice and } \\
\text { pharmacy education, and } \\
\text { include evaluation of } \\
\text { research designs. }\end{array}$ & $\begin{array}{l}\text { - Systematic review and narrative synthesis. } \\
\text { - Use of SM to enhance e-professionalism and } \\
\text { pharmacy education. } \\
\text { - Pharmacists (educators, preceptors, interns and } \\
\text { students). }\end{array}$ & $\begin{array}{l}\text { - } 24 \text { papers included. } \\
\text { - Survey methods were used in } 17 \text { studies; focus groups in } \\
\text { two; interviews in one; and direct observation in } \\
\text { seven. } \\
\text { - The use of SM in pharmacy is increasing but findings are } \\
\text { not generalizable to other countries. } \\
\text { - SM in general and SNSs were used mainly for personal } \\
\text { reasons. Wikis, Facebook, and Twitter were used in } \\
\text { pharmacy education with positive feedback from } \\
\text { students. }\end{array}$ \\
\hline $\begin{array}{l}\text { Best et al, } \\
2014 \text { (UK) } \\
\text { [36] }\end{array}$ & $\begin{array}{l}\text { To examine the } \\
\text { influence of SM on } \\
\text { adolescent well-being. }\end{array}$ & $\begin{array}{l}\text { - Systematic narrative review and theoretical } \\
\text { framework. } \\
\text { - The influence of SM on adolescent well-being. } \\
\text { - Adolescents (over } 19 \text { y/o excluded; mean age of } \\
\text { 19). }\end{array}$ & $\begin{array}{l}\text { - } 43 \text { papers included. } \\
\text { - Survey research (55\%), followed by qualitative (12\%), } \\
\text { longitudinal (12\%), content analysis (11\%), } \\
\text { experimental (4\%), case control (3\%) and mixed } \\
\text { method studies (3\%). } \\
\text { - SNSs can be beneficial and harmful for mental } \\
\text { wellbeing. } \\
\text { - Benefits include increased self-esteem, perceived social } \\
\text { support, increased social capital, safe identity } \\
\text { experimentation and increased opportunity for self- }\end{array}$ \\
\hline
\end{tabular}

Online Journal of Public Health Informatics * ISSN 1947-2579* http://ojphi.org * 10(2):e215, 2018 
disclosure. Harmful effects were increased exposure to harm, social isolation, depression and cyberbullying.

\begin{tabular}{|c|c|c|c|}
\hline & & & $\begin{array}{l}\text { disclosure. Harmful effects were increased exposure } \\
\text { to harm, social isolation, depression and cyber- } \\
\text { bullying. }\end{array}$ \\
\hline $\begin{array}{l}\text { Brunner et al, } \\
2015 \\
\text { (Australia) } \\
\text { [17] }\end{array}$ & $\begin{array}{l}\text { To examine the use of } \\
\text { SM on patients with } \\
\text { traumatic brain injury } \\
\text { (TBI). }\end{array}$ & $\begin{array}{l}\text { - Systematic review with qualitative synthesis. } \\
\text { - The benefits, harms; barriers, facilitators of SM } \\
\text { use in patient populations who have had a } \\
\text { TBI. } \\
\text { - Patients with TBI. }\end{array}$ & $\begin{array}{l}\text { - } 16 \text { papers included. } \\
\text { - Conference abstracts/proceedings ( } 43 \%) \text {, qualitative } \\
\text { studies ( } 19 \%) \text {, qualitative descriptive studies (13\%), } \\
\text { systematic review (6\%), case series (6\%), thesis (6\%), } \\
\text { narrative literature review (6\%). } \\
\text { - SM use in TBI rehabilitation can increase social support; } \\
\text { further investigation is needed into the benefits of SM } \\
\text { for social support. There is little information on the } \\
\text { use of SM in TBI patients after injury. Online safety is } \\
\text { a risk and cognitive and behavioural disabilities are } \\
\text { barriers. }\end{array}$ \\
\hline
\end{tabular}

\begin{tabular}{|c|c|c|c|}
\hline $\begin{array}{l}\text { Campos et al, } \\
2016 \text { (Mexico) } \\
\text { [51] }\end{array}$ & $\begin{array}{l}\text { To examine use of SM } \\
\text { by the elderly to } \\
\text { promote independent } \\
\text { living, social } \\
\text { integration, to improve } \\
\text { health, reduce cognitive } \\
\text { decline, and prevent } \\
\text { early death. }\end{array}$ & $\begin{array}{l}\text { - Systematic review. } \\
\text { - Use of ambient and SNSs in social integration of } \\
\text { the elderly / older adults. } \\
\text { - Elderly populations. }\end{array}$ & $\begin{array}{l}\text { - } 53 \text { papers included. } \\
\text { - Controlled trial (24), non-controlled (5), case series, 2), } \\
\text { controlled case series (4), other (18). } \\
\text { - There was an increase in participation of older adults in } \\
\text { SNSs who can benefit from the use of ambient and } \\
\text { social technologies. Different technologies have been } \\
\text { suggested to socially integrate the elderly, but they } \\
\text { can be expensive. } \\
\text { - SNSs are a way to promote socialization of elderly } \\
\text { adults. }\end{array}$ \\
\hline
\end{tabular}




\section{3 papers included.}

\begin{tabular}{|c|c|c|c|}
\hline $\begin{array}{l}\text { Capurro et al, } \\
2014 \text { (Chile) } \\
\text { [48] }\end{array}$ & $\begin{array}{l}\text { To identify the best } \\
\text { uses of SNSs for public } \\
\text { health research and } \\
\text { practice and to identify } \\
\text { gaps. }\end{array}$ & $\begin{array}{l}\text { - Systematic review. } \\
\text { - Use of SNSs for public health research and } \\
\text { practice. } \\
\text { - Hard-to-reach populations (adolescents, patients } \\
\text { with chronic non-communicable diseases and } \\
\text { individuals at risk for STDs and HIV). }\end{array}$ & $\begin{array}{l}\text { - } 73 \text { papers included. } \\
\text { - Cross-sectional observational (63), RCTs (4), systematic } \\
\text { review (1), other (5). } \\
\text { - Use of SM is increasing but difficult to measure its } \\
\text { effects. Issue is mostly studied in high-income } \\
\text { countries. } \\
\text { - SM may be effective in studying diverse populations, in } \\
\text { sexual health and alcohol, tobacco or substance abuse. }\end{array}$ \\
\hline $\begin{array}{l}\text { Cartledge et al, } \\
2013 \text { (UK) [37] }\end{array}$ & $\begin{array}{l}\text { To examine } \\
\text { implementation of } \\
\text { SNSs as interventions } \\
\text { in healthcare education; } \\
\text { use of SNSs by students } \\
\text { for educational } \\
\text { purposes. }\end{array}$ & $\begin{array}{l}\text { - Systematic review. } \\
\text { - Use of SNSs in medical education. } \\
\text { - Medical, pharmacy and nursing students. } \\
\text { Undergraduates and post-grads in health. }\end{array}$ & $\begin{array}{l}\text { - } 9 \text { papers included studies. } \\
\text { - This review examined } 9 \text { case studies where SM was used } \\
\text { in medical education. } \\
\text { - Medical educators can use SM to benefit learning. There } \\
\text { were no problems with professionalism and positive } \\
\text { feedback was received from learners. } \\
\text { - However, there was no solid evidence that SM is equally } \\
\text { or more effective than other media in medical } \\
\text { education. }\end{array}$ \\
\hline $\begin{array}{l}\text { Chang et al, } \\
2013 \text { (USA) } \\
{[26]}\end{array}$ & $\begin{array}{l}\text { To systematically } \\
\text { describe the use and } \\
\text { impact of social media } \\
\text { in online weight } \\
\text { management } \\
\text { interventions. }\end{array}$ & $\begin{array}{l}\text { - Systematic review. } \\
\text { - Effects of SM in online weight management. } \\
\text { - Adults }\end{array}$ & $\begin{array}{l}\text { - } 20 \text { papers included. } \\
\text { - RCTs (20). } \\
\text { - Few studies measure the effects of SM in online weight } \\
\text { management interventions; its impact is still } \\
\text { unknown. } \\
\text { - Findings are consistent with previous systematic reviews } \\
\text { on Internet-based behavioral interventions and } \\
\text { electronic peer-to-peer support group interventions, } \\
\text { which have found that the effect of the technology } \\
\text { being studied was not isolated; thus, their } \\
\text { effectiveness is not known. }\end{array}$ \\
\hline
\end{tabular}


- 60 papers included.

\begin{tabular}{|c|c|c|c|}
\hline $\begin{array}{l}\text { Charles-Smith } \\
\text { et al, 2015 } \\
\text { (USA) [27] }\end{array}$ & $\begin{array}{l}\text { To identify and target } \\
\text { specific SM tools to use } \\
\text { in public health } \\
\text { interventions. }\end{array}$ & $\begin{array}{l}\text { - Systematic review. } \\
\text { - The use of SM in disease surveillance practice } \\
\text { and outbreak management to support public } \\
\text { health. } \\
\text { - General population. }\end{array}$ & $\begin{array}{l}\text { - } 60 \text { papers included. } \\
\text { - Case studies, cohort studies, retrospective studies. } \\
\text { - SM is shown to be effective in improving public health, } \\
\text { and may be effective at disease surveillance, and at } \\
\text { identifying adolescent populations displaying } \\
\text { substance abuse, especially alcohol, sexual behaviour. } \\
\text { SM can improve community health outcomes for at- } \\
\text { risk adolescents. } \\
\text { - Public health should integrate SM analytics into disease } \\
\text { surveillance and outbreak management practice. }\end{array}$ \\
\hline $\begin{array}{l}\text { Chen et al, } \\
2016 \text { (Hong } \\
\text { Kong) [45] }\end{array}$ & $\begin{array}{l}\text { To examine the effects } \\
\text { of ICT interventions on } \\
\text { reducing social } \\
\text { isolation of the elderly. }\end{array}$ & $\begin{array}{l}\text { - Systematic review using narrative synthesis. } \\
\text { - The effects of SM on one or more attributes of } \\
\text { social isolation among elderly. } \\
\text { - Elderly populations. }\end{array}$ & $\begin{array}{l}\text { - } 25 \text { papers included. } \\
\text { - RCTs (6), cohort studies (6), surveys (4), other (9). } \\
\text { - SM tools may be effective in tackling social isolation of } \\
\text { the elderly, but not for every senior. Usage should be } \\
\text { tailored and other platforms should be studied } \\
\text { empirically. } \\
\text { - Research on other types of ICTs (eg, mobile phone- } \\
\text { based instant messaging apps) should be conducted to } \\
\text { promote understanding of ICT-based social-isolation } \\
\text { interventions for the elderly. }\end{array}$ \\
\hline $\begin{array}{l}\text { Cheston et al, } \\
2013 \text { (USA) } \\
\text { [28] }\end{array}$ & $\begin{array}{l}\text { To examine the use of } \\
\text { SM in medical } \\
\text { education to determine } \\
\text { outcomes, challenges } \\
\text { and opportunities. }\end{array}$ & $\begin{array}{l}\text { - Systematic review. } \\
\text { - The use of SM interventions in medical } \\
\text { education. } \\
\text { - Medical students in all years, physicians, } \\
\text { specialists, residents, fellows. }\end{array}$ & $\begin{array}{l}\text { - } 14 \text { papers included. } \\
\text { - Nine studies (64\%) used a single-group cross-sectional } \\
\text { or posttest design, whereas four studies (29\%) } \\
\text { employed a two-group nonrandomized design. One } \\
\text { RCT (7\%). } \\
\text { - SM is associated with improved exam scores, attitudes } \\
\text { (e.g., empathy), and skills (e.g., reflective writing). } \\
\text { - Opportunities related to incorporating SM were } \\
\text { promoting learner engagement (71\% of studies), } \\
\text { feedback (57\%), and collaboration and professional } \\
\text { development (both 36\%). }\end{array}$ \\
\hline
\end{tabular}


- Commonly cited challenges were technical issues (43\%), variable learner participation (43\%), and privacy/security concerns (29\%).

\begin{tabular}{|c|c|c|c|}
\hline & & & $\begin{array}{l}\text { - Commonly cited challenges were technical issues (43\%), } \\
\text { variable learner participation (43\%), and } \\
\text { privacy/security concerns (29\%). }\end{array}$ \\
\hline $\begin{array}{l}\text { Dyson et al, } \\
2016 \text { (Canada) } \\
\text { [43] }\end{array}$ & $\begin{array}{l}\text { To examine the use of } \\
\text { SM in deliberate self- } \\
\text { harming behaviours. }\end{array}$ & $\begin{array}{l}\text { - Systematic review. } \\
\text { - The use of SM related to self-harm or suicidality } \\
\text { in children and / or adolescents } \\
\text { - Teens and adolescents aged } 12 \text { to } 21 \text {. }\end{array}$ & $\begin{array}{l}\text { - } 26 \text { papers included. } \\
\text { - Cross-sectional observational (19\%), descriptive (35\%), } \\
\text { qualitative (42\%), mixed (4\%). } \\
\text { - SM can create a sense of community and platforms used } \\
\text { by those who ‘self harm' are described as supportive. } \\
\text { - Support included suggestions for formal treatment, } \\
\text { advice on stopping self-harming behaviour, and } \\
\text { encouragement. Harms included normalizing and } \\
\text { accepting self-harming; discussion of motivation or } \\
\text { triggers, concealment, suicidal ideation or plans; and } \\
\text { live depictions of self-harm acts. }\end{array}$ \\
\hline $\begin{array}{l}\text { Eysenbach et } \\
\text { al, } 2004 \\
\text { (Canada) [42] }\end{array}$ & $\begin{array}{l}\text { To compile and } \\
\text { evaluate the evidence } \\
\text { on the effects on health } \\
\text { and social outcomes of } \\
\text { computer-based peer- } \\
\text { to-peer (P2P) } \\
\text { communities and } \\
\text { electronic self-support } \\
\text { groups. }\end{array}$ & $\begin{array}{l}\text { - Systematic review. } \\
\text { - The effect on health \& social outcomes of P2P } \\
\text { online support and electronic self-support } \\
\text { groups. } \\
\text { - Adults and patients. }\end{array}$ & $\begin{array}{l}\text { - } 45 \text { papers included. } \\
\text { - } 20 \text { RCTs, } 3 \text { meta-analyses, } 2 \text { non RCTs, one cohort } \\
\text { study, and } 11 \text { before and after studies, other. } \\
\text { - The outcomes measured most often were depression and } \\
\text { social support; but most studies showed no effect. } \\
\text { There is no evidence to support concerns over SM } \\
\text { harming people. } \\
\text { - "Effect" of P2P communities is unclear. Studies are } \\
\text { confounded by effects of co-interventions. }\end{array}$ \\
\hline
\end{tabular}


- 62 papers included.

- Study types of the papers were not mentioned.

- 3DVWs offer innovative ways to perform health activities within six categories: academic education, professional education, treatment, modeling, lifestyle, and evaluation.

- Most research focused on education in health care, and most studies were undertaken in just two countries, the United States and the United Kingdom.

\section{Gold et al,}

2011

(Australia)

[19]

To examine the extent

to which SNSs are used

for sexual health promotion and describe the breadth of these activities.

Systematic searches and content analysis of SM sites.

- The use of SNSs for sexual health promotion.

- Young people (no age ranges given).

Golder et al,
2015 (UK) [38]

2015 (UK) [38]

To summarize the prevalence, frequency and comparative value of information on the adverse events of healthcare interventions from user comments and videos in social media.

\section{- Systematic review using narrative synthesis.}

- The number and frequency of sharing adverse events on SM and user comments.

- Population not mentioned.

\section{- 178 activities included.}

- Study types are not applicable.

- SNSs are being used to deliver health promotion, although the activities have not been described or evaluated for their effectiveness in improving health outcomes.

- Recommends cost-effectiveness studies in the future.

\section{- 51 papers included.}

- Studies assessed over 174 social media sites with discussion forums (71\%) being the most popular. Adverse events in SM varied from $0.2 \%$ to $8 \%$ of posts.

- There are more adverse events in SM, particularly in sharing 'symptom' related and 'mild' adverse events.

- Cost-effectiveness analysis of all pharmacovigilance systems, including social media is urgently required.

\section{Griffiths et al,}

\section{9}

(Australia)

To review the available evidence concerning the effect of Internet

- Systematic review.

[20] support groups (ISGs) on depressive - The use of ISGs by patients with depression. - Patients with a depression diagnosis.

\section{- 31 papers included.}

- More than half of the studies reported a positive effect of ISGs on depressive symptoms. However, only two (20\%) of these studies employed a control group.

- Studies with lower design quality tended to be associated with more positive outcomes $(\mathrm{P}=.07)$. Overall, studies of breast cancer ISGs were more likely to 
report a reduction in depressive symptoms than

\begin{tabular}{|c|c|c|c|}
\hline & & & $\begin{array}{l}\text { report a reduction in depressive symptoms than } \\
\text { studies of other ISG types. }\end{array}$ \\
\hline $\begin{array}{l}\text { Househ et al, } \\
2014 \text { (Saudi } \\
\text { Arabia) [55] }\end{array}$ & $\begin{array}{l}\text { To explore the range of } \\
\text { SM platforms used by } \\
\text { patients and examine } \\
\text { the benefits and } \\
\text { challenges of using } \\
\text { these tools from a } \\
\text { patient perspective. }\end{array}$ & $\begin{array}{l}\text { - Systematic review. } \\
\text { - The use of SM platforms as used by patients. } \\
\text { - Patients and health consumers. }\end{array}$ & $\begin{array}{l}\text { - } 12 \text { papers included. } \\
\text { - Four studied programs or interventions that use SM; } \\
\text { three focused on literature reviews, three were } \\
\text { observational, one was a survey, and one was } \\
\text { conceptual in nature. } \\
\text { - SM can have a positive effect in community engagement, } \\
\text { information sharing, data collection, appointment } \\
\text { setting, prescription notifications, providing health } \\
\text { information, engagement of the elderly, improved } \\
\text { participation, autonomy, motivation, trust, and } \\
\text { perceived self-efficacy. } \\
\text { - Concerns are privacy, security, the usability of social } \\
\text { media programs, manipulation of identity, and } \\
\text { misinformation. }\end{array}$ \\
\hline $\begin{array}{l}\text { Jin et al, } 2014 \\
\text { (Hong Kong) } \\
\text { 46] }\end{array}$ & $\begin{array}{l}\text { To examine the effects } \\
\text { of educational } \\
\text { technologies on student } \\
\text { learning and staff } \\
\text { engagement in } \\
\text { problem-based learning. }\end{array}$ & $\begin{array}{l}\text { - Systematic review. } \\
\text { - The use of educational tech in problem-based } \\
\text { learning. } \\
\text { - Postsecondary students and tutors in medicine, } \\
\text { dentistry, speech and hearing sciences. }\end{array}$ & $\begin{array}{l}\text { - } 28 \text { papers included. } \\
\text { - The review demonstrates the generally positive effect of } \\
\text { educational technologies in PBL. Positive outcomes } \\
\text { for learning include providing rich, authentic } \\
\text { problems and/or case contexts for learning; student } \\
\text { development of medical expertise; making } \\
\text { disciplinary thinking explicit; providing a platform to } \\
\text { elicit articulation, collaboration, and reflection; } \\
\text { reducing perceived cognitive load. } \\
\text { - Limitations included cumbersome scenarios, } \\
\text { infrastructure requirements, and the need for staff and } \\
\text { student support in light of the technological demands } \\
\text { of new affordances. }\end{array}$ \\
\hline
\end{tabular}




\begin{tabular}{|l|l|l|l|}
\hline $\begin{array}{l}\text { Jones et al, } \\
\text { 2014 (USA) }\end{array}$ & $\begin{array}{l}\text { To examine the } \\
\text { effectiveness of SM and } \\
\text { text messaging } \\
\text { interventions designed } \\
\text { to increase sexually } \\
\text { transmitted disease } \\
\text { (STD) knowledge. }\end{array}$ & $\begin{array}{l}\text { - Systematic review. } \\
\text { The use of SM to increase STD knowledge and } \\
\text { reduced risky behaviours. }\end{array}$ & $\begin{array}{l}\text { - Young adults aged } 15 \text { through } 24 \text { years. } \\
\bullet \text { RCTs (6), feasibility study (2), pre/post-test design (3). } \\
\end{array}$ \\
& & & $\begin{array}{l}\text { There is some evidence indicating that SM and text } \\
\text { messaging increases knowledge regarding the } \\
\text { prevention of STDs. The interventions may also affect } \\
\text { behaviour, such as screening/testing for STDs, sexual } \\
\text { risk behaviors, and STD acquisition, but the evidence } \\
\text { for effect is weak. }\end{array}$ \\
\end{tabular}

\begin{tabular}{|c|c|c|c|}
\hline $\begin{array}{l}\text { Koskan et al, } \\
2014 \text { (USA) } \\
{[30]}\end{array}$ & $\begin{array}{l}\text { The use and taxonomy } \\
\text { of SM in cancer-related } \\
\text { studies. }\end{array}$ & $\begin{array}{l}\text { - Systematic review. } \\
\text { - The use of SM by cancer patients, and its impact } \\
\text { on the digital divide and health literacy; } \\
\text { cancer disparities. } \\
\text { - Cancer care communities }\end{array}$ & $\begin{array}{l}\text { - } 69 \text { papers included. } \\
\text { - Use of SM in cancer from } 1996 \text { to } 2007 \text { focuses on } \\
\text { discussion forums, message boards and support group } \\
\text { websites. By 2008, researchers began to view the } \\
\text { benefits of blogging during cancer treatment and } \\
\text { survivorship. Intervention studies were not reported } \\
\text { until } 2010 \text {. } \\
\text { - Most research analyses the content of SM forums where } \\
\text { users asynchronously post or respond, share } \\
\text { resources, reliable cancer information or emotional } \\
\text { support. } \\
\text { - Adults aged } 18 \text { to } 49 \text { make up large group using } \\
\text { Facebook and Twitter which might be useful for } \\
\text { cancer screening. }\end{array}$ \\
\hline $\begin{array}{l}\text { Laranjo et al, } \\
2015 \\
\text { (Portugal) [54] }\end{array}$ & $\begin{array}{l}\text { To examine the use and } \\
\text { effectiveness of } \\
\text { interventions using } \\
\text { social networking sites } \\
\text { (SNSs) to change health } \\
\text { behaviours. }\end{array}$ & $\begin{array}{l}\text { - Systematic review and meta-analysis. } \\
\text { - Effectiveness of SNSs in changing health } \\
\text { behavior-related outcomes. } \\
\text { - Participants were diverse in age; three studies } \\
\text { recruited students, and two studies involved } \\
\text { young adults. }\end{array}$ & $\begin{array}{l}\text { - } 12 \text { papers included. } \\
\text { - RCTs (9), quasi-experimental (3) studies. } \\
\text { - Overall, SNS interventions appear to show statistically } \\
\text { significant effect in promoting health-related } \\
\text { behaviours. } \\
\text { - Most studies evaluated multi-component interventions, } \\
\text { posing problems in isolating specific effects of SNSs. }\end{array}$ \\
\hline
\end{tabular}


- Health behavior change theories were seldom mentioned but two innovative studies used 'network alteration', showing a positive effect.

\begin{tabular}{|c|c|c|c|}
\hline & & & $\begin{array}{l}\text { - Health behavior change theories were seldom mentioned } \\
\text { but two innovative studies used 'network alteration', } \\
\text { showing a positive effect. }\end{array}$ \\
\hline $\begin{array}{l}\text { Luo et al, } 2015 \\
\text { (Hong Kong) } \\
\text { [47] }\end{array}$ & $\begin{array}{l}\text { To examine the } \\
\text { effectiveness of social } \\
\text { networking } \\
\text { interventions (SNIs) in } \\
\text { HIV prevention. }\end{array}$ & $\begin{array}{l}\text { - Systematic review. } \\
\text { - Effectiveness of SNIs as an intervention in HIV } \\
\text { prevention. } \\
\text { - Sexually active young adults, teens. }\end{array}$ & $\begin{array}{l}\text { - } 11 \text { papers included. } \\
\text { - RCTs (11). } \\
\text { - The strength of using SN in HIV prevention is moderate. } \\
\text { Some studies show SNIs help high-risk populations } \\
\text { modify their behaviours. There is insufficient } \\
\text { evidence overall. }\end{array}$ \\
\hline $\begin{array}{l}\text { Maher et al, } \\
2014 \\
\text { (Australia) } \\
\text { [21] }\end{array}$ & $\begin{array}{l}\text { To systematically } \\
\text { review the current level } \\
\text { of evidence regarding } \\
\text { the effectiveness of } \\
\text { online social network } \\
\text { (OSN) health behaviour } \\
\text { interventions. }\end{array}$ & $\begin{array}{l}\text { - Systematic review and qualitative synthesis. } \\
\text { - Uses of OSNs to deliver health behaviour change } \\
\text { interventions. } \\
\text { - Adults or children were included, regardless of } \\
\text { health status (healthy, or participants with } \\
\text { specific health conditions or diseases). }\end{array}$ & $\begin{array}{l}\text { - } 10 \text { papers included. } \\
\text { - RCTS (6), pre-post studies (4) using a mix of health } \\
\text { social networks ( } \mathrm{n}=2 \text { ), research OSN websites }(\mathrm{n}=3) \text {, } \\
\text { and multi-component delivered via pre-existing OSNs } \\
\text { (Facebook } n=4 \text { and Twitter } n=1 \text { ). Nine studies } \\
\text { reported significant improvements in aspects of health } \\
\text { behaviour change. } \\
\text { - Effect sizes were small and statistically non-significant. } \\
\text { Engagement in studies was relatively low, 5-15\% } \\
\text { fidelity. } \\
\text { - It is unclear whether OSN-based interventions are } \\
\text { equally useful for all health behaviours, for the long } \\
\text { term, or whether they may be more effective for some } \\
\text { than others. }\end{array}$ \\
\hline
\end{tabular}


- 16 papers included.

- SM is used with low levels of media richness and presence (e.g., discussion boards, bulletin boards). Trials assessing SM interventions aimed at modifying risk factors for non-communicable diseases showed SM use improved primary outcomes, but poor study quality limits generalizability.

- Further trials should isolate effects of SM and effects of media richness of platforms. Studies that integrate SM into interventions had a greater effect for primary outcomes (ie., for weight loss, physical activity, healthy eating).

- 98 papers included.

- There are some benefits to using SM in health communication such as increased interactions, greater access to tailored information, peer support, public health surveillance, and potential to influence public policy.

- Health information on SM needs to be monitored for quality and reliability; users' confidentiality and privacy need to be maintained. Eight gaps in the literature and key recommendations for future research were provided.

- 19 papers included.

- RCTs (7), non-RCTs (5), cross-sectional (3), operational research (3), case-control study (1).

- Text messaging, patient portals and computer reminders may increase rates of vaccine-immunization. Youth are willing to use Facebook for health-related reminders.

- Data is insufficient overall on the effects of SM, email and smartphone applications. However, it is estimated that youth in 18-29 y/o group receive 87.7 messages a day. 
42 papers included.

\begin{tabular}{|c|c|c|c|}
\hline $\begin{array}{l}\text { Patel et al, } \\
2015 \text { (UK) [39] }\end{array}$ & $\begin{array}{l}\text { To evaluate clinical } \\
\text { outcomes from } \\
\text { applications of } \\
\text { contemporary SM in } \\
\text { chronic disease; } \\
\text { develop a conceptual } \\
\text { taxonomy of SM uses. }\end{array}$ & $\begin{array}{l}\text { - Systematic review. } \\
\text { - Uses (and categorisation) of SM in chronic } \\
\text { disease. } \\
\text { - Adults (more than } 18 \text { years of age). }\end{array}$ & $\begin{array}{l}\text { - } 42 \text { papers included. } \\
\text { - Quantitative(27), qualitative(12), mixed method studies } \\
\text { (3) } \\
\text { - Overall impact of social media on chronic disease was } \\
\text { variable, with } 48 \% \text { of studies indicating benefit, } 45 \% \\
\text { neutral or undefined, and } 7 \% \text { suggesting harm. } \\
\text { Among studies showing benefit, } 85 \% \text { used Facebook } \\
\text { or blogs, and } 40 \% \text { were based within the domain of } \\
\text { support. Using social media to provide social, } \\
\text { emotional, or experiential support in chronic disease, } \\
\text { especially with Facebook and blogs, appears most } \\
\text { likely to improve patient care. }\end{array}$ \\
\hline $\begin{array}{l}\text { Rolls et al, } \\
2016 \\
\text { (Australia) } \\
{[22]}\end{array}$ & $\begin{array}{l}\text { To review use of SM by } \\
\text { health professionals in } \\
\text { developing virtual } \\
\text { communities that } \\
\text { facilitates professional } \\
\text { networking, knowledge } \\
\text { sharing, and evidence- } \\
\text { informed practice. }\end{array}$ & $\begin{array}{l}\text { - Systematic searches with integrative review } \\
\text { synthesis. } \\
\text { - The use of SM by health professionals for a } \\
\text { variety of purposes such as information- } \\
\text { sharing and networking. } \\
\text { - Health care professionals (physicians, nurses, } \\
\text { midwives, pharmacist, social worker, allied } \\
\text { health personnel). }\end{array}$ & $\begin{array}{l}\text { - } 72 \text { papers included. } \\
\text { - } 44 \text { qualitative, } 20 \text { mixed methods, and } 8 \text { literature } \\
\text { reviews. } \\
\text { - There is emerging evidence that health professionals use } \\
\text { SM to develop virtual communities and to share } \\
\text { domain knowledge. These virtual communities, } \\
\text { however, currently reflect tribal behaviors of } \\
\text { clinicians that may continue to limit knowledge } \\
\text { sharing. }\end{array}$ \\
\hline $\begin{array}{l}\text { Sawesi et al, } \\
2016 \text { (USA) } \\
\text { [31] }\end{array}$ & $\begin{array}{l}\text { To examine use of IT } \\
\text { platforms and SM to } \\
\text { engage patients in } \\
\text { healthcare and change } \\
\text { in health behaviours. }\end{array}$ & $\begin{array}{l}\text { - Systematic review. } \\
\text { • Education of young people and their health. } \\
\text { - Adolescents and health professionals. }\end{array}$ & $\begin{array}{l}\text { - } 170 \text { papers included. } \\
\text { - RCTs (112), case study (7), cohort study (19), cross- } \\
\text { sectional analysis (15), quasi-experimental trials (17). } \\
\text { - IT platforms can enhance patient engagement and } \\
\text { improve health outcomes. 88.8\% (151/170) of studies } \\
\text { showed positive impact on patient behaviour and } \\
82.9 \% \text { reported high levels of improvement in patient } \\
\text { engagement. Only } 47.1 \% \text { referenced specific } \\
\text { behaviour theories and } 33.5 \% \text { assessed usability of IT } \\
\text { platforms. }\end{array}$ \\
\hline
\end{tabular}


- 3 papers included.

- Facebook may provide the most effective access to adolescents but are moving to Twitter and Instagram.

- The reviewed studies did not show significant positive or negative results from using Facebook interventions.

- Adolescents have a tendency to progress to newer media, and often create a hidden "secret" world in using SM.

\section{Smailhodzic et}

al, 2016

To provide an oveview of the effects of SM use

(Netherlands)

[52]

for health-related

reasons on patients and

their relationship with

- The effects on patients (both positive and negative) of using SM.

- Patients.

healthcare

professionals.

- 22 papers were included.

- Quantitative (9), qualitative (7), mixed method (6) studies.

- Uses of SM were for social support, emotional and esteem support, expression, network and information support. Effects of SM were enhanced psychological, enhanced subjective well-being (and diminished), addiction to social SM, loss of privacy, being targeted for promotion.

- SM use by patients was found to affect the healthcare professional and patient relationship by leading to more equal communication between patient and provider, but increased switching of doctors, and suboptimal interaction.

\section{Smith et al,} To evaluate the use, 2014 (UK) [11] attitudes and perceptions of both teachers and students towards SM platforms (Facebook and Twitter) in healthcare higher - Systematic review.

- Uses, attitudes and perceptions of SM use in healthcare.

- Medical students in all years, physicians, specialists, residents, fellows, pharmacy, allied health.

\section{- 16 papers included.}

- This review provides some qualified support for use of Facebook and Twitter in healthcare higher education as part of a "blended" approach to classroom teaching.

- SM is used to enhance communication and increase accessibility, exposure and interactivity of students to real-world practices and expertise.

- Students perceive SM to be of value, but the role of faculty members in a predominantly "social” community has been acknowledged as a potential conflict. 


\begin{tabular}{|c|c|c|c|}
\hline $\begin{array}{l}\text { Song et al, } \\
2014 \text { (Korea) } \\
\text { [50] }\end{array}$ & $\begin{array}{l}\text { To explore the } \\
\text { relationship between } \\
\text { Facebook use and } \\
\text { loneliness. }\end{array}$ & $\begin{array}{l}\text { - Systematic review and meta-analysis. } \\
\text { - The relationship between using Facebook and } \\
\text { loneliness. } \\
\text { - General Facebook users. }\end{array}$ & $\begin{array}{l}\text { - } 8 \text { papers included. } \\
\text { - Researchers observed a significant overall effect in the } \\
\text { positive relationship between Facebook use and } \\
\text { loneliness. } \\
\text { - People who are lonely may use Facebook to enhance } \\
\text { social resources they lack offline. Lack of social } \\
\text { support may lead to loneliness, which in turn, leads to } \\
\text { Facebook use. Lonely individuals may benefit from } \\
\text { Facebook but more research is needed to examine its } \\
\text { effects. } \\
\text { - Excessive problematic use of SM is an important issue } \\
\text { for future research because unhealthy, compulsive use } \\
\text { is likely an important factor in using Facebook and } \\
\text { feeling lonely. }\end{array}$ \\
\hline $\begin{array}{l}\text { Stellefson et al, } \\
2013 \text { (USA) } \\
\text { [32] }\end{array}$ & $\begin{array}{l}\text { To review effectiveness } \\
\text { of Web } 2.0 \text { self- } \\
\text { management } \\
\text { interventions for older } \\
\text { adults (mean age } \geq 50 \text { ) } \\
\text { with one or more } \\
\text { chronic disease(s). }\end{array}$ & $\begin{array}{l}\text { - Systematic review. } \\
\text { - The use of SM as interventions for self- } \\
\text { management in older adults. } \\
\text { - Broad population of chronically ill older patients. }\end{array}$ & $\begin{array}{l}\text { - } 15 \text { papers included. } \\
\text { - RCTs (11), randomized cluster, quasi-experimental, } \\
\text { cross-sectional, qualitative designs } \\
\text { - Self-managed patients felt greater self-efficacy in talking } \\
\text { to health providers and receiving feedback and } \\
\text { support. Asynchronous tools (eg, email, discussion } \\
\text { boards) and progress tracking were useful for self- } \\
\text { management. } \\
\text { - SM engagement may be associated with improvements } \\
\text { in health behaviours (eg, physical activity) and health } \\
\text { status. } \\
\text { - Factors influencing long term use of SM are not yet } \\
\text { understood. Dropouts may have led to distorted } \\
\text { effects. }\end{array}$ \\
\hline
\end{tabular}


- 15 papers included.

\begin{tabular}{|c|c|c|c|}
\hline $\begin{array}{l}\text { Swanton et al, } \\
2015 \\
\text { (Australia) } \\
\text { [24] }\end{array}$ & $\begin{array}{l}\text { To examine effects of } \\
\text { new media } \\
\text { interventions on sexual } \\
\text { health behaviours and } \\
\text { factors moderating the } \\
\text { effect on those } \\
\text { behaviours. }\end{array}$ & $\begin{array}{l}\text { - Systematic review and meta-analysis. } \\
\text { - The effects of new media on changing sexual } \\
\text { health behaviours. } \\
\text { - Sexually active young adults, teens. }\end{array}$ & $\begin{array}{l}\text { - } 15 \text { papers included. } \\
\text { - Twelve studies examined the effects of new-media on } \\
\text { condom use; nine looked at effect on STD testing. } \\
\text { - SM interventions lead to increased condom use and STD } \\
\text { testing but the effects were not homogeneous. Using } \\
\text { SM to encourage testing is more effective with } \\
\text { women than with men, and generally more effective } \\
\text { in younger adults. } \\
\text { - Interactivity, target population and study design } \\
\text { influenced efficacy of the interventions. }\end{array}$ \\
\hline $\begin{array}{l}\text { Taggart et al, } \\
2015 \text { (USA) } \\
\text { [33] }\end{array}$ & $\begin{array}{l}\text { To examine the use of } \\
\text { SM to communicate } \\
\text { about HIV prevention } \\
\text { and treatment. }\end{array}$ & $\begin{array}{l}\text { - Systematic review. } \\
\text { - Using social media to communicate about HIV } \\
\text { prevention and treatment. } \\
\text { - Social media users: health professionals, } \\
\text { clinicians, general users having HIV-related } \\
\text { interests. }\end{array}$ & $\begin{array}{l}\text { - } 35 \text { papers included. } \\
\text { - Qualitative (9), quantitative (11) and mixed method (15) } \\
\text { studies. } \\
\text { - SM is used among diverse users and the frequency of } \\
\text { use, satisfaction and effects of SM varied across } \\
\text { studies. } \\
\text { - Access to information, communicability, anonymity, } \\
\text { sense of social and emotional support are key reported } \\
\text { benefits. } \\
\text { - Technology barriers, lack of privacy, cost and lack of } \\
\text { physical interaction are the main disadvantages. }\end{array}$ \\
\hline $\begin{array}{l}\text { Theng et al, } \\
2015 \\
\text { (Singapore) } \\
\text { [56] }\end{array}$ & $\begin{array}{l}\text { To examine the use of } \\
\text { video games, } \\
\text { gamification and virtual } \\
\text { environments in } \\
\text { diabetes management. }\end{array}$ & $\begin{array}{l}\text { - Systematic review. } \\
\text { - The self-management of diabetes using video } \\
\text { games and virtual media. } \\
\text { - Patients living with diabetes. }\end{array}$ & $\begin{array}{l}\text { - } 10 \text { papers included. } \\
\text { - RCTs (3), quasi-experimental (5), focus group discussion } \\
\text { (1) experimental (1). } \\
\text { - Four studies employed video games as intervention, three } \\
\text { utilized virtual reality environments and three studies } \\
\text { adopted principles from gamification and relevant } \\
\text { theory. } \\
\text { - Overall, video games were effective in diabetes but } \\
\text { drawing strong conclusions is a challenge. } \\
\text { - Gamification and virtual environments increase patients' } \\
\text { intrinsic motivation and positive reinforcement. }\end{array}$ \\
\hline
\end{tabular}

Online Journal of Public Health Informatics * ISSN 1947-2579* http://ojphi.org * 10(2):e215, 2018 


\begin{tabular}{|c|c|c|c|}
\hline $\begin{array}{l}\text { Toma et al, } \\
2014 \text { (UK) [41] }\end{array}$ & $\begin{array}{l}\text { To summarise the } \\
\text { evidence surrounding } \\
\text { the role of online social } \\
\text { networking services in } \\
\text { diabetes care. }\end{array}$ & $\begin{array}{l}\text { - Systematic review and meta-analysis. } \\
\text { - The use of SNSs to assess HbA1c as a measure } \\
\text { of glycaemic control with Type } 1 \text { or Type } 2 \\
\text { diabetes. } \\
\text { - Patients with diabetes. }\end{array}$ & $\begin{array}{l}\text { - } 34 \text { papers included. } \\
\text { - SNSs can improve HbA1c control in diabetics. SNS } \\
\text { offers a novel approach to improving glycaemic } \\
\text { control compared with standard management } \\
\text { especially in Type } 2 \text { diabetes. } \\
\text { - SNSs may be more efficient for patients with Type } 2 \\
\text { rather than Type } 1 \text { disease. Larger randomised } \\
\text { controlled trials in addition to cost-effectiveness } \\
\text { studies are needed to understand the use of SNSs in } \\
\text { diabetes care. }\end{array}$ \\
\hline $\begin{array}{l}\text { Whitehead et } \\
\text { al, } 2016 \\
\text { (Australia) } \\
\text { [25] }\end{array}$ & $\begin{array}{l}\text { To assess the } \\
\text { effectiveness of mobile } \\
\text { phone and tablet apps in } \\
\text { self-management of key } \\
\text { symptoms of long-term } \\
\text { conditions. }\end{array}$ & $\begin{array}{l}\text { - Systematic review. } \\
\text { - Use of mobile apps to improve disease-specific } \\
\text { clinical outcomes. } \\
\text { - Adult patients with long-term conditions. }\end{array}$ & $\begin{array}{l}\text { - } 9 \text { papers included. } \\
\text { - Apps were shown to be somewhat effective in improving } \\
\text { outcomes for patients managing their chronic } \\
\text { diseases, especially those with diabetes and chronic } \\
\text { lung problems. } \\
\text { - Barriers are language and literacy, cost, availability and } \\
\text { connectivity; cost-effectiveness studies are needed to } \\
\text { demonstrate the impact and value of apps. } \\
\text { - Without good patient motivation and adherence, mHealth } \\
\text { interventions such as apps are likely to be ineffective. }\end{array}$ \\
\hline $\begin{array}{l}\text { Williams et al, } \\
2014 \text { (Canada) } \\
\text { [44] }\end{array}$ & $\begin{array}{l}\text { To examine the use of } \\
\text { SM to promote healthy } \\
\text { diet and exercise in the } \\
\text { general population. }\end{array}$ & $\begin{array}{l}\text { - Systematic review. } \\
\text { - The use of SM interventions to promote healthy } \\
\text { behaviours. } \\
\text { - Adult populations (mostly middle-aged } \\
\text { Caucasian women of mid-to-high } \\
\text { socioeconomic status). }\end{array}$ & $\begin{array}{l}\text { - } 22 \text { papers included. RCTs. } \\
\text { - SM is commonly used as an intervention but there is } \\
\text { little evidence that SM interventions demonstrate a } \\
\text { significant benefit for improving healthy diet and } \\
\text { exercise. } \\
\text { - Most research is from the US affecting generalizability. } \\
\text { No significant differences between SM interventions } \\
\text { and alternate or no intervention controls in promoting } \\
\text { healthy behaviours. This may be due to low levels of } \\
\text { participation and the difficulty in affecting } \\
\text { behavioural changes as seen across different } \\
\text { interventions. While initial positive changes may be } \\
\text { seen, these are often not sustained. }\end{array}$ \\
\hline
\end{tabular}




\begin{tabular}{|c|c|c|c|}
\hline $\begin{array}{l}\text { Willis et al, } \\
2016 \text { (USA) } \\
{[34]}\end{array}$ & $\begin{array}{l}\text { To examine weight } \\
\text { management } \\
\text { interventions delivered } \\
\text { by online social } \\
\text { networks (OSNs) to } \\
\text { improve body weight, } \\
\text { body composition, and } \\
\text { chronic disease risk } \\
\text { factors. }\end{array}$ & $\begin{array}{l}\text { - Systematic review. } \\
\text { - Using OSNs in managing body weight and } \\
\text { chronic disease risk factors. } \\
\text { - Adult populations. }\end{array}$ & $\begin{array}{l}\text { - } 5 \text { papers included. } \\
\text { - In all } 5 \text { studies, weight loss, though modest, was } \\
\text { statistically significant in OSN groups independent of } \\
\text { intervention length. Three studies (60\%) reported } \\
\text { significant decreases in body weight when OSNs were } \\
\text { paired with health educator guidance and support. } \\
\text { - One study reported significant weight loss of } \geq 5 \% \text {. There } \\
\text { is great potential for weight management delivered } \\
\text { through OSNs. Interventions supported by } \\
\text { professional guidance generate a more positive effect } \\
\text { than self-guided OSNs. } \\
\text { - To date, cost-effectiveness of OSN interventions in } \\
\text { weight management has not been evaluated. }\end{array}$ \\
\hline
\end{tabular}




\section{Appendix D. A thematic analysis of the 42 papers presented as a conceptual map}

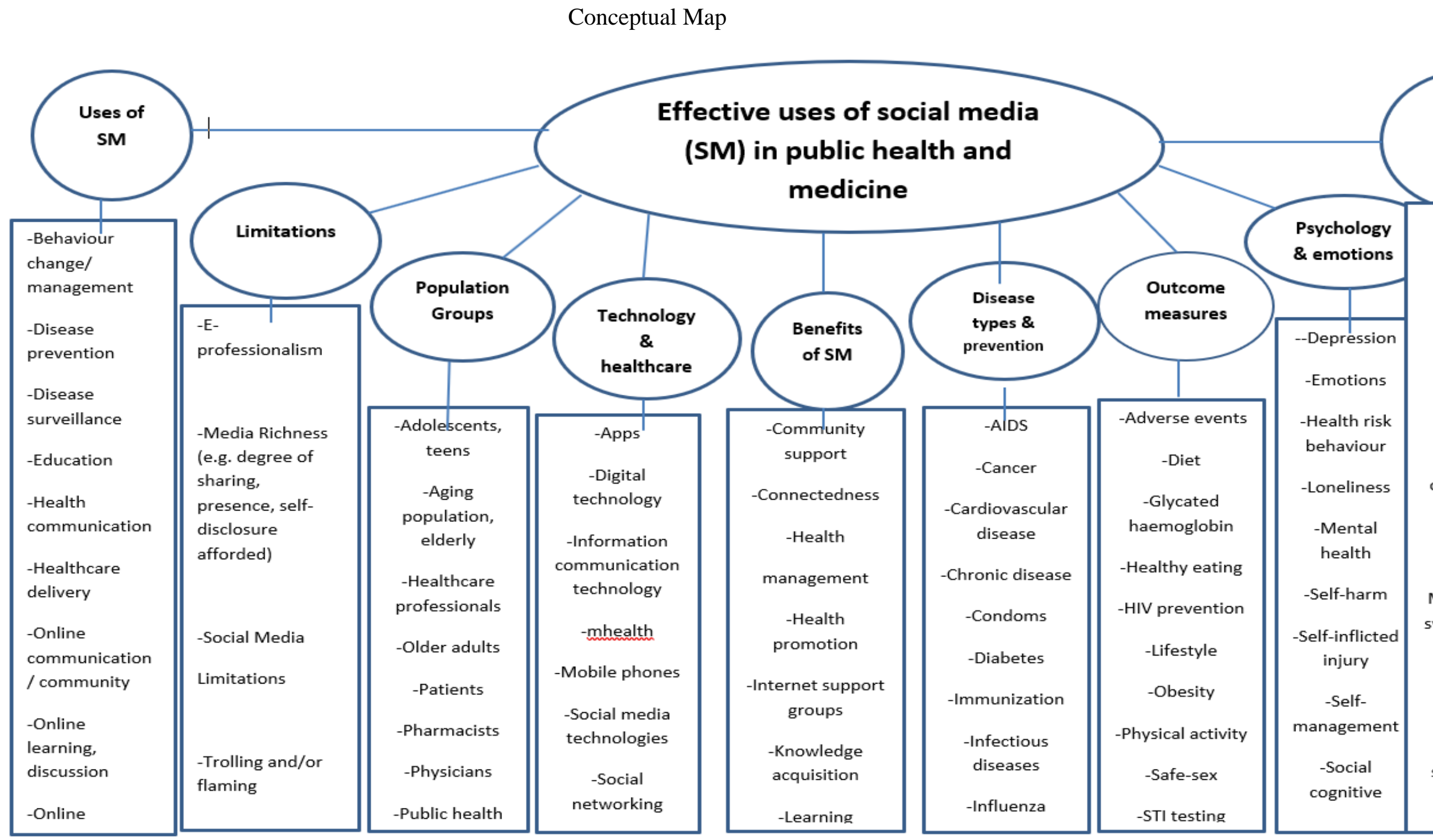

